$\frac{1}{1 / 16} \mid 9^{2} \operatorname{gn} \theta$
0111

OAK RIDGE NATIONAL LABORATORY

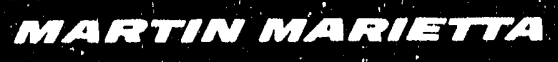

ORNL/TM-12068

Gas Separations Using Inorganic Membranes

\author{
B. Z. Egan \\ S. P. N. Singh \\ D. E:. Fain \\ G. E. Roettger \\ D. E. White
}


This report has ben reproduced directly from the best available copy.

Available to DOE and DOE contractors from the Office of Scientific and Technical Iniormation, P.O. Box 62, Oak Ridge, TN 37831; prices available from (615) 676-8401, FTS 626-8401.

Available to the public from the National Technical Information Service, U.S. Depertment of Commerce, 5285 Port Royal Rd., Springfield, VA 22161.

This report was prepared as an account of work sponsored by an agency $c$; the United States Government. Neither the United States Government nor any agency thereof, nor any of their employees, makes any warranty, express or implied, or assumes any legal llability or responsibility for the accuracy, com. pleteness, or usefulness of any information, apparatus, product, or process disclosed, or represents that its use would not infringe privately owned rights. Reference herein to any specific commercial product, process, or service by trade name, trademark, manufacturer, or otherwise, does not necessarily constitute or imply its endorsement, recommendation, or favoring by the Unitea States Government or any agency thereof. The views and opinions of authors expressed herein do not necessarily state or reflect those of the United States Government or any agency thereot. 
Chemical Technology Division

\section{GAS SEPARATIONS USING INORGANIC MEMBRANES}

B. Z. Egan

S. P. N. Singh

Chemical Technology Division

Oak Ridge National Laboratory

Oak Ridge, TN 37831

D. E. Fain

G. E. Roettger

D. E. White

Technical Division

Oak Ridge K-25 Site

Oak Ridge, TN 37831

Date Published - April 1992

Prepared for the

U. S. Department of Energy

Office of Fossil Energy

Morgantown Energy Technology Center

AR\&TD Components Program

AA 1510000

Prepared by the

Oak Ridge National Laboratory

Oak Ridge, Tennessee 37831 managed by

MARTIN MARIETTA ENERGY SYSTEMS, INC. for the

U.S. DEPARTMENT OF ENERGY

under contract DE-AC05-84OR2140) 


\section{CONTENTS}

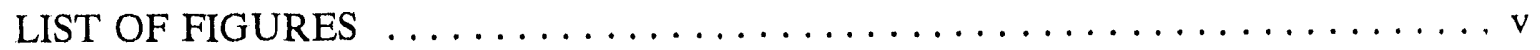

LIST OF TABLES $\ldots \ldots \ldots \ldots \ldots \ldots \ldots \ldots \ldots \ldots \ldots \ldots \ldots \ldots \ldots$

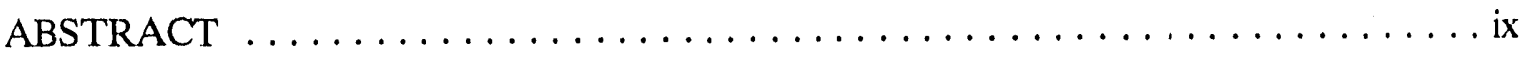

1. INTRODUCTION $\ldots \ldots \ldots \ldots \ldots \ldots \ldots \ldots \ldots \ldots \ldots \ldots \ldots \ldots \ldots$

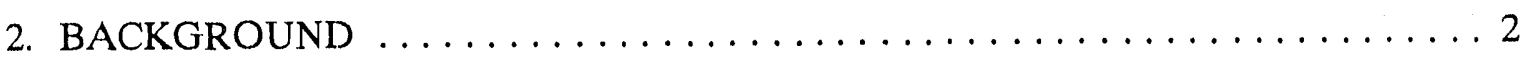

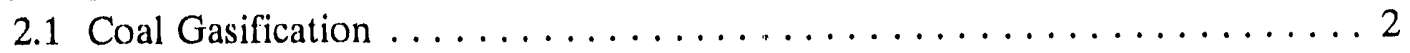

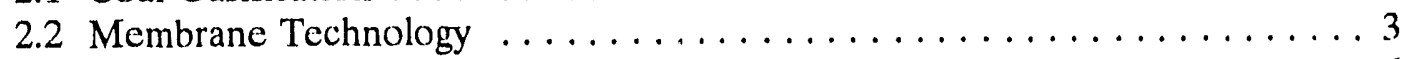

2.3 Gas Transport Mechanisms . . . . . . . . . . . . . . . . 6

2.4 Related Membrane Research . . . . . . . . . . . . . . . 7

3. TECHNICAL APPROACH $\ldots \ldots \ldots \ldots \ldots \ldots \ldots \ldots \ldots \ldots \ldots$

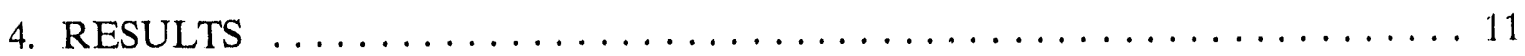

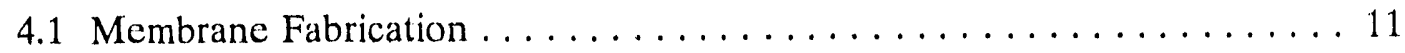

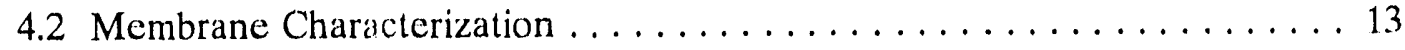

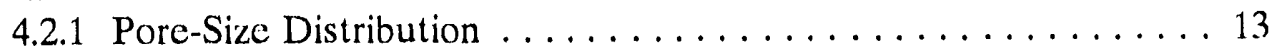

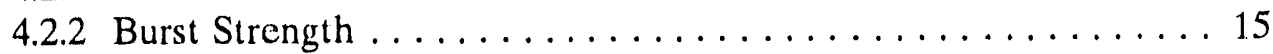

4.3 Membrane Test System .......................... 15

4.4 Permeability Measurements . . . . . . . . . . . . . . . . . . 19

4.5 Room Temperature Tests . . . . . . . . . . . . . . . . . 21

4.6 High-Pressure Tests . . . . . . . . . . . . . . . . . . . . . 25

4.7 Permeability at Higher Permeate Gas Pressures . . . . . . . . . . . . . . . . . 29

4.8 Permeability Measurements at Higher Temperatures . . . . . . . . . . . . . 29

4.9 Separation of Gas Mixtures . . . . . . . . . . . . . . . 32

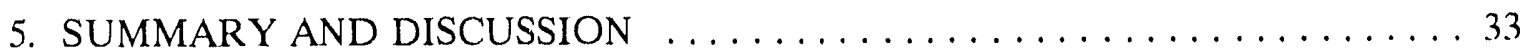

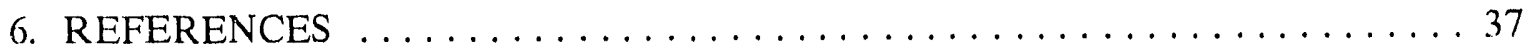

7. PROJECT-RELATED PUBLICATIONS AND PRESENTATIONS $\ldots \ldots \ldots . .40$

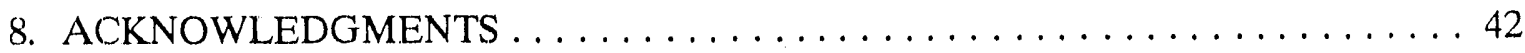




\section{LIST OF FIGURES}

Figure

Page

1. (A) Schematic of a typical entrained bed gasification-combined cycle process.

(B) Schematic of a conceptual process using a membrane gas separation

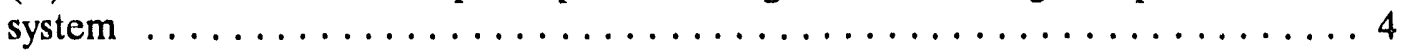

2. Conceptual process for hydrogen separation from coal gasification gases $\ldots \ldots 5$

3. Pore-size distribution of an early membrane fabricated at the Oak Ridge K-25

Site ................................... 14

4. Pore-size distribution of an improved membrane fabricated at the Oak Ridge K-25 Site ............................. 16

5. Test apparatus for gas permeability measurements $\ldots \ldots \ldots \ldots \ldots \ldots$

6. Photograph of the gas permeability test system $\ldots \ldots \ldots \ldots \ldots \ldots \ldots$

7. Typical gas permeabilities of a membrane fabricated at the Oak Ridge K-25

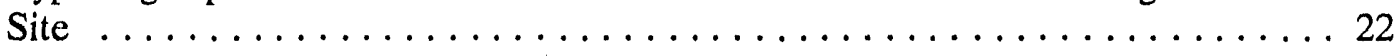

8. Separation factors for helium/carbon dioxide and helium/nitrogen for Series $\mathrm{A}$ membranes with different pore sizes $\ldots \ldots \ldots \ldots \ldots \ldots \ldots \ldots \ldots \ldots$

9. Gas permeabilities of an alumina membrane fabricated at the Oak Ridge K-25

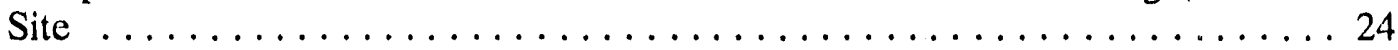

10. Separation factors for helium/carbon dioxide and helium/nitrogen for Series B

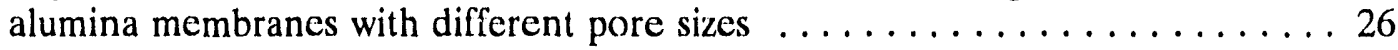

11. Gas permeabilities of a fabricated alumina membrane at room temperature . . 27

12. Helium and nitrogen permeabilities of a fabricated alumina membrane at high

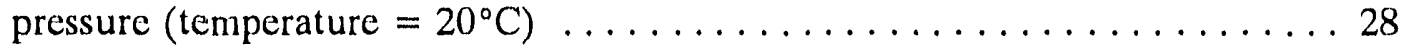

13. Gas chromatograms of permeate and residue gases from a test on a gas mixture using a fabricated alumina membrane: (A) residue, (B) permeate . . . 34 


\section{LIST OF TABLES}

$\underline{\text { Table }}$

$\underline{\text { Page }}$

1. Calculated separation factors based on molecular size with various pore

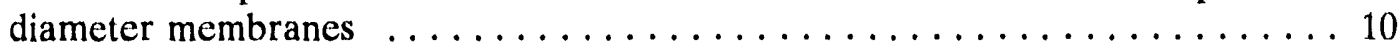

2. Burst strength of typical tubular alumina membranes $\ldots \ldots \ldots \ldots \ldots \ldots 17$

3. Summary of gas permeability measurements at higher permeate gas

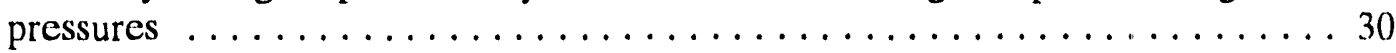

4. Comparison of gas fluxes through an alumina membrane at higher

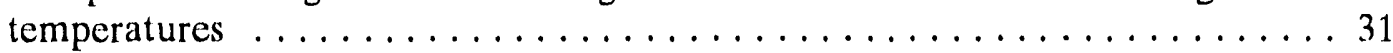

5. Composition of simulated coal gasifier gas mixtures $\ldots \ldots \ldots \ldots \ldots \ldots$ 


\begin{abstract}
This report summarizes the results from a research and development program to develop, fabricate, and evaluate inorganic membranes for separating gases at high temperatures and pressures in hostile process environments encountered in fossil energy conversion processes such as coal gasification. The primary emphasis of the research was on the separation and recovery of hydrogen from synthesis gas. Major aspects of the prograin included assessment of the worldwide research and development activity related to gas separations using inorganic membranes, identification and selection of candidate membrane materials, fabrication and characterization of membranes using porous membrane technology developed at the Oak Ridge K-25 Site, and evaluation of the separations capability of the fabricated membranes in terms of permeabilities and fluxes of gases.

Porous, tubular alumina membranes with a diameter of $\sim 9 \mathrm{~mm}$ and a wall thickness of $\sim 0.5 \mathrm{~mm}$, having pore radii ranging from $<10 \AA$ to $>150 \AA$, have been fabricated and tested. These membranes are capable of withstanding $>600 \mathrm{psi}$ (4 MPa) pressure and operating at temperatures up to $1000^{\circ} \mathrm{F}$.

The permeabilities of pure gases, including $\mathrm{He}, \mathrm{N}_{2}, \mathrm{CO}_{2}$, and $\mathrm{SF}_{6}$, and the separation of gas mixtures containing $\mathrm{H}_{2}, \mathrm{CO}, \mathrm{CO}_{2}, \mathrm{~N}_{2}$, and $\mathrm{CH}_{4}$ were measured over a range of pressures and temperatures. The primary mechanism of gas transport across the membranes appears to be Knudsen diffusion. When the membranes were tested for separating gas mixtures, the permeate gas was enriched in hydrogen, primarily at the expense of carbon dioxide.
\end{abstract}




\title{
GAS SEPARATIONS USING INORGANIC MEMBRANES
}

\section{B. Z. Egan}

S. P. N. Singh

\section{Chemical Technology Division \\ Oak Ridge National Laboratory \\ Oak Ridge, TN 37831}

\author{
D. E. Fain \\ G. E. Roettger \\ D. E. White \\ Technical Division \\ Oak Ridge K-25 Site \\ Oak Ridge, TN 37831
}

\section{INTRODUCTION}

This report summarizes the results from a research and development program to develop, fabricate, and evaluate inorganic membranes for separating gases at high temperatures and pressures in hostile process environments encountered in fossil energy conversion processes such as coal gasification. The primary emphasis of the research was on the separation and recovery of hydrogen from synthesis gas. Major aspects of the program included assessment of the worldwide research and development (R\&D) activity related to gas separations using inorganic membranes, identilication and selection of candidate membrane materials, fabrication and characterization of membranes using porous membrane technology developed at the Oak Ridge K-25 Site, and evaluation of the separations capability of the fabricated membranes in terms of permeabilities and fluxes of gases. 


\section{BACKGROUND}

\subsection{COAL GASIFICATION}

Hydrogen is an important and valuable raw material that has numerous uses in the chemical and fuel industries. Synthesis gas produced in coal gasification is primarily $\mathrm{H}_{2}$ and $\mathrm{CO}$, but may also contain $\mathrm{N}_{2}, \mathrm{CO}_{2}, \mathrm{H}_{2} \mathrm{~S}, \mathrm{H}_{2} \mathrm{O}$, aliphatic hydrocarbons, and other gases, depending on the particular gasification process. Isolating the $\mathrm{H}_{2}$ from the other gases requires low-temperature operations, such as solvent extraction, pressure-swing adsorption (at 40 to $100^{\circ} \mathrm{F}$ ) or cryogenic separation. If technology could be developed to separate the hydrogen from the raw gas at high temperatures, it would significantly lower the cost of hydrogen production.

Commercially, at present, bulk removal of acid gases from raw process gas, such as synthesis gas containing hydrogen, is carried out by using solvent scrubbing processes like methyldiethanolamine (MDEA), Selexol, and Rectisol. Although solvent scrubbing processes can be designed to operate at temperatures up to $450^{\circ} \mathrm{F}$ (e.g., the Benfield and Catacaro processes), most commercial acid gas removal processes operate at temperatures below $200^{\circ} \mathrm{F}$. Consequently, the gases are cooled to near room temperature during cleanup and separation. Research is being conducted to develop acid gas removal processes, such as the zinc ferrite process, capable of operating at temperatures up to $1200^{\circ} \mathrm{F}$. The proposed membrane separation process would operate at conditions closer to the exit gas conditions from typical entrained flow gasifiers than the presently known processes. Satisfactory operations under these adverse operating conditions would significantly improve coal conversion process elficiencies. 
Figure $1(\mathrm{~A})$ is a simplified block flow diagram of a typical integrated, entrained-bed coal gasification-combined cycle (IGCC) process. Present technology requires cooling theproduct gases from $\sim 1500^{\circ} \mathrm{F}$ to $\sim 100^{\circ} \mathrm{F}$ to permit removal of carbon dioxide, hydrogen sulfide, and other contaminant gases. The cleaned fuel gas $\left(\mathrm{CO}-\mathrm{H}_{2}\right)$ must then be reheated to 500 to $600^{\circ} \mathrm{F}$ for downstream combustion in a gas turbine to generate power. The efficiency of the process would be increased substantially if the hydrogen and carbon monoxide could be recovered at the higher downstream operating temperature. A block flow diagram for a conceptual membrane gas separation system for this application is shown in Fig. 1(B). Briefly stated, the gas cooling and the gas cleanup system would be replaced with a membrane separation system operating at high temperature.

An alternative conceptual process might include a shift reactor to convert the carbon monoxide to hydrogen and increase the hydrogen yield. The hydrogen would then be separated using a membrane separation process (Fig. 2). This would simplify the gas separation problem while allowing the recovery of the carbon monoxide energy value.

\subsection{MEMBRANE TECHNOLOGY}

Significant advances in the field of membrane technology have occurred during the last few years. ${ }^{1}$ Recent developments in this area have led to major improvements in both performance and economics in gas processing applications. The development of membranes with high selectivity and flux capabilities has led to the commercial-scale use of membranes to separate gaseous components from gas mixtures. For example, modular menibrane separation systems are now commercially available for hydrogen purification and recovery in ammonia plants, manufacture of oxygen-enriched air, sweetening of sour natural gas, and recovery of carbon dioxide from wellhead gas in enhanced oil recovery operations. ${ }^{2-7}$ 

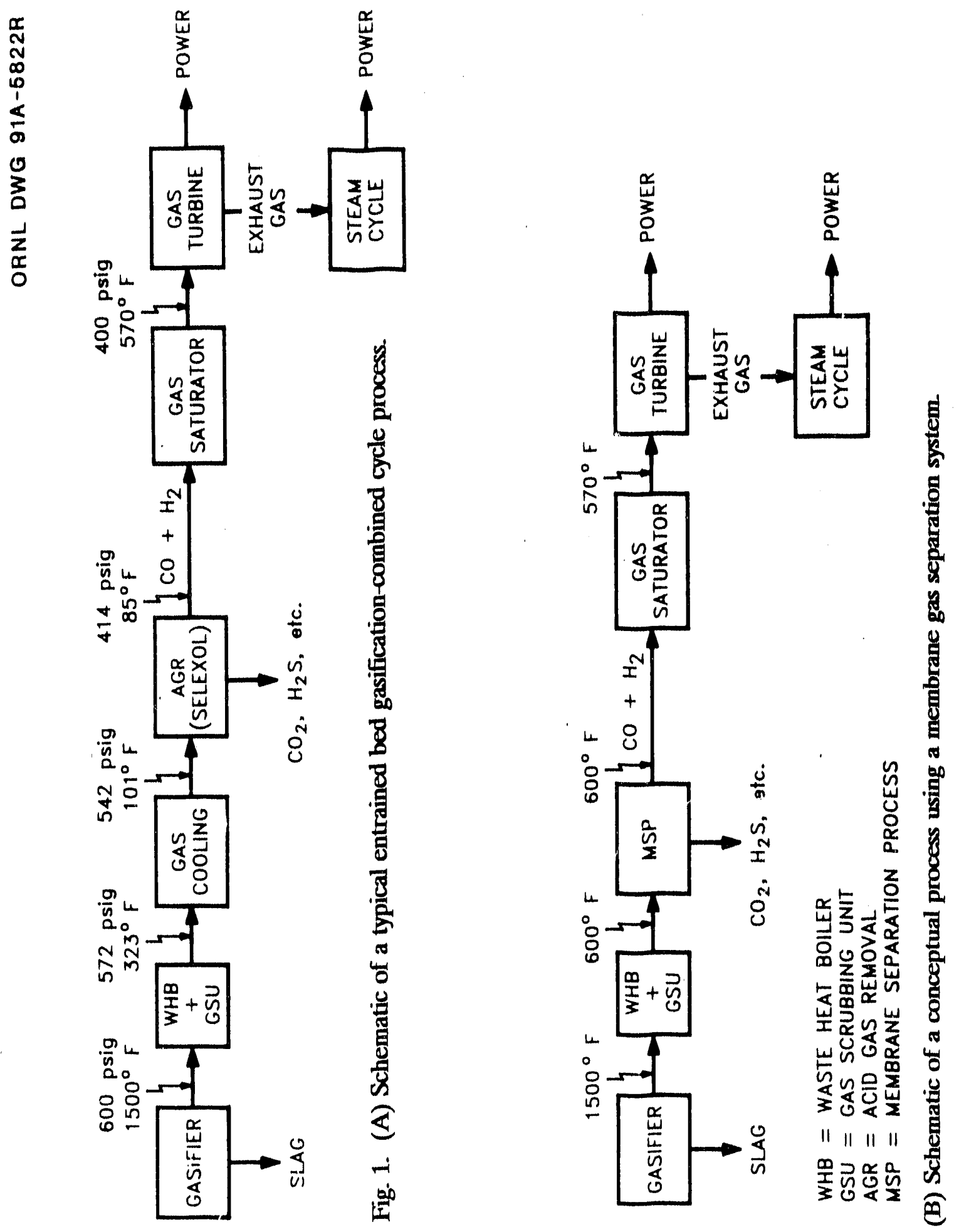


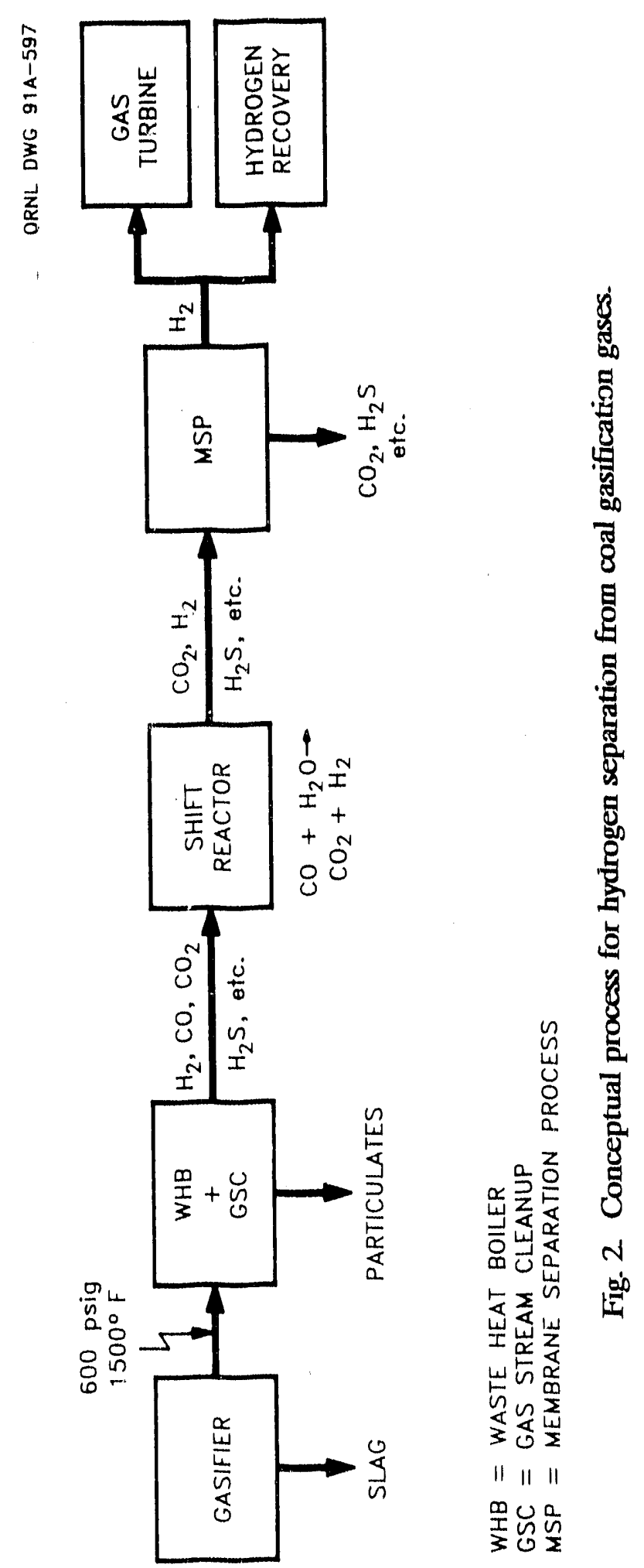


However, the membranes used in these systems are thin film composites of polymeric organic materials, which have limited thermal stability and are susceptible to abrasion and chemical attack in harsh environments. Therefore, these membranes have not found applications in separation processes where hot, reactive gases are encountered. Inorganic membranes could potentially be used in such hostile enviroṇments.

Until recently, inorganic membranes have been used primarily for microfiltration and ultrafiltration. Although the permeability of several gases in various inorganic materials has been studied, there has been no large-scale application of inorganic membrane separations of gases except for uranium enrichment. Gas permeabilities of metals such as W, Mo, $\mathrm{Fe}, \mathrm{Cu}$, $\mathrm{Ni}, \mathrm{Ag}$, and $\mathrm{Pd}$, and alloys of these mctals have been studied. ${ }^{8}$ Ceramics and porous metals have also been tested as supports for deposition of metal films of $\mathrm{V}$ and $\mathrm{Al}$, and for membrane coatings of $\mathrm{ZrO}_{2}, \mathrm{NiO}$, and $\mathrm{TiO}_{2}$. Inorganic polymeric membranes, such as polyphosphazenes and organic-inorganic membranes containing heteropoly acids and salts, have also been prepared..$^{9-11}$

\subsection{GAS TRANSPORT MECHANISMS}

The major types of gas transport through porous membranes are viscous flow, freemolecule or Knudsen flow, surface diffusion, capillary condensation, molecular sieving, and ion exchange. If the pores are much larger than the mean free path of the gas molecules, then viscous flow predominates and no significant gas separation occurs. If the pores are much smaller than the mean free path of the gas molecules, then Knudsen or free-molecuie diffusion occurs, and the separation factor for binary gas mixtures can be estimated from the square root of the ratio of molecular weights; the lower molecular weight molecules with a higher velocity move through the pores faster. As the pore size approaches the size of a gas 
molecule, molecular sieving or screening can occur. If the membrane has pore sizes between the diameters of the smaller and larger molecules, then only the smaller molecule can permeate, and the separation factor approaches infinity. Gas adsorption on the surface of the pore wall may result in surface flow or surface diffusion, and it also effectively decreases the pore size. Capillary condensation occurs when the pore becomes filled or partially filled with a condensed phase; then condensate flow and/or vaporization of the condensate may affect the apparent gas flow or flux through the membrane. Other gas transport mechanisms such as ion exchange, solution diffusion, and solid diffusion involve interaction beiween gases and the membrane.

\subsection{RELATED MEMBRANE RESEARCH}

Inorganic membranes are being investigated worldwide for separating gases on a laboratory scale. ${ }^{12}$ Membrane materials include porous metals, glass, and ceramics.

Metals, particularly palladium and palladium alloys, have been used to separate hydrogen isotopes from each other and hydrogen from various other gases. ${ }^{13}$ The separation of hydrogen from gases such as $\mathrm{CO}_{2}, \mathrm{~N}_{2}, \mathrm{H}_{2} \mathrm{~S}, \mathrm{CO}$, and $\mathrm{CH}_{4}$ with porous glass membranes has been demonstrated at the laboratory scale. ${ }^{14-16}$ Metallic oxides, porous glass, and ceramics have been used to separate a large variety of gases; many involve the separation of hydrogen from other gases. Alumina and silica are the most frequently used materials for metallic oxide membranes. ${ }^{17,18}$ Membrane preparation methods are based on sol-gel, ${ }^{19}$ slipcasting, ${ }^{20}$ anodic oxidation (metallic oxides), ${ }^{21}$ and phase separation/leaching (porous glass) ${ }^{22}$ techniques.

Metallic membranes have been used primarily for separating hydrogen isotopes and for separating hydrogen from other gases. Many of the studies are directed toward separating 
hydrogen, deuterium, and tritium isotopes. Frequently, palladium is alloyed with silver to improve the physical and mechanical properties of the membrane material.

The separation of several gases with porous glass membranes has been shown at the laboratory scale. Some of the gases that have been separated using f.Jrous glass membranes include $\mathrm{H}_{2}, \mathrm{He}, \mathrm{Ar}, \mathrm{N}_{2}, \mathrm{O}_{2}, \mathrm{CO}_{2}, \mathrm{CO}$, and light hydrocarbons. Many of the applications of porous glass for gas separations have come from Japan.

The most frequently used materials for motallic oxide membranes are alumina and silica. Some membranes contain mixtures of these along with other oxides such as zirconia or titania. Alumina is also frequently used as the support for other membrane materials..$^{23}$ Most of the metallic oxide membranes are made by sol-gel/slipcasting or anodic oxidation techniques. Other preparation techniques include chemical vapor deposition, sputtering,

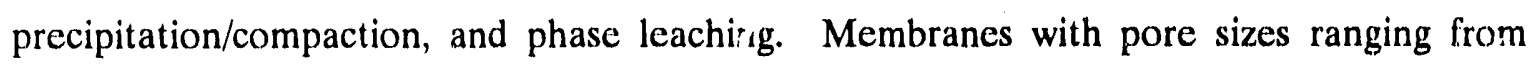
several angstroms to nearly a micrometer have been prepared. The permeation behavior of several gases hạs been studied using alumina or alumina-containing membranes. These gases include $\mathrm{H}_{2}, \mathrm{~N}_{2}, \mathrm{CO}_{2}, \mathrm{He}, \mathrm{Ar}, \mathrm{O}_{2}, \mathrm{H}_{2} \mathrm{~S}, \mathrm{SO}_{2}, \mathrm{H}_{2} \mathrm{O}$, alcohols, and light hydrocarbons.

The Department of Energy has supported programs at Alcoa, SRI International, CeraMem, Air Products, Oak Ridge National Laboratory, Oak Ridge K-25 Site, Idaho National Engineering Laboratory, and several universities to develop and test inorganic membranes for high-temperature gus separations.

Several universities have established membrane research centers or programs to carry out membrane R\&D. Many have financial support from industry. Various aspects being addressed by these centers include: preparation and characterization of inorganic polymers, ceramics and metals; membrane applications; modeling and simulation; membrane reactor development; transport mechanisms; and membrane catalysis. 
Research on ceramic membranes in Europe is concentrated at the Ecole Nationale Superieure de Chimie de Montpellier, Laboratoire de Physicochimie des Materiaux, in France, and at Twente University of Technology, Enschede, the Netherlands.

\section{TECHNICAL APPROACH}

Several porous inorganic materials that could be used as membranes are commercially available in disk, tube, and monolith form. Materials include metals, glass, and ceramics with pore sizes ranging from a few nanometers to isveral micrometers. ${ }^{12}$ However, the minimum pore size is in the range of 30 to $40 \AA$. This limits their applicability primarily to filtration. While some gas separations can be achieved with these materials (primarily by Knudsen diffusion), it is generally accepted that smaller pore sizes or other membrane modifications will be needed for effecient gas separations. Of course, it is necessary to maintain high gas permeability while reducing the pore size. Generally, ti:s means developing a very thin membrane.

Table 1 shows the effect of membrane pore diameter on the calculated separation factors for binary mixtures of hydrogen with $\mathrm{N}_{2}, \mathrm{CO}_{2}, \mathrm{CO}$, and $\mathrm{H}_{2} \mathrm{~S}$. At larger pore sizes, the primary transport mechanism is free-molecule or Knudsen flow, and the separation factor can be estimated from the square root of the ratio of the molecular weights of the gases. However, as the pore size decreases, some molecular screening can occur. At some point, if the membrane has no pores greater than the diameter of the larger gas molecuie, then the membrane will not be permeable to the molecule and the separation factor will approach infinity. In practice, however, there will be a distribution of pore sizes and other transport mechanisms may be operative. Also, as the pore size decreases, the membrane porosity may 


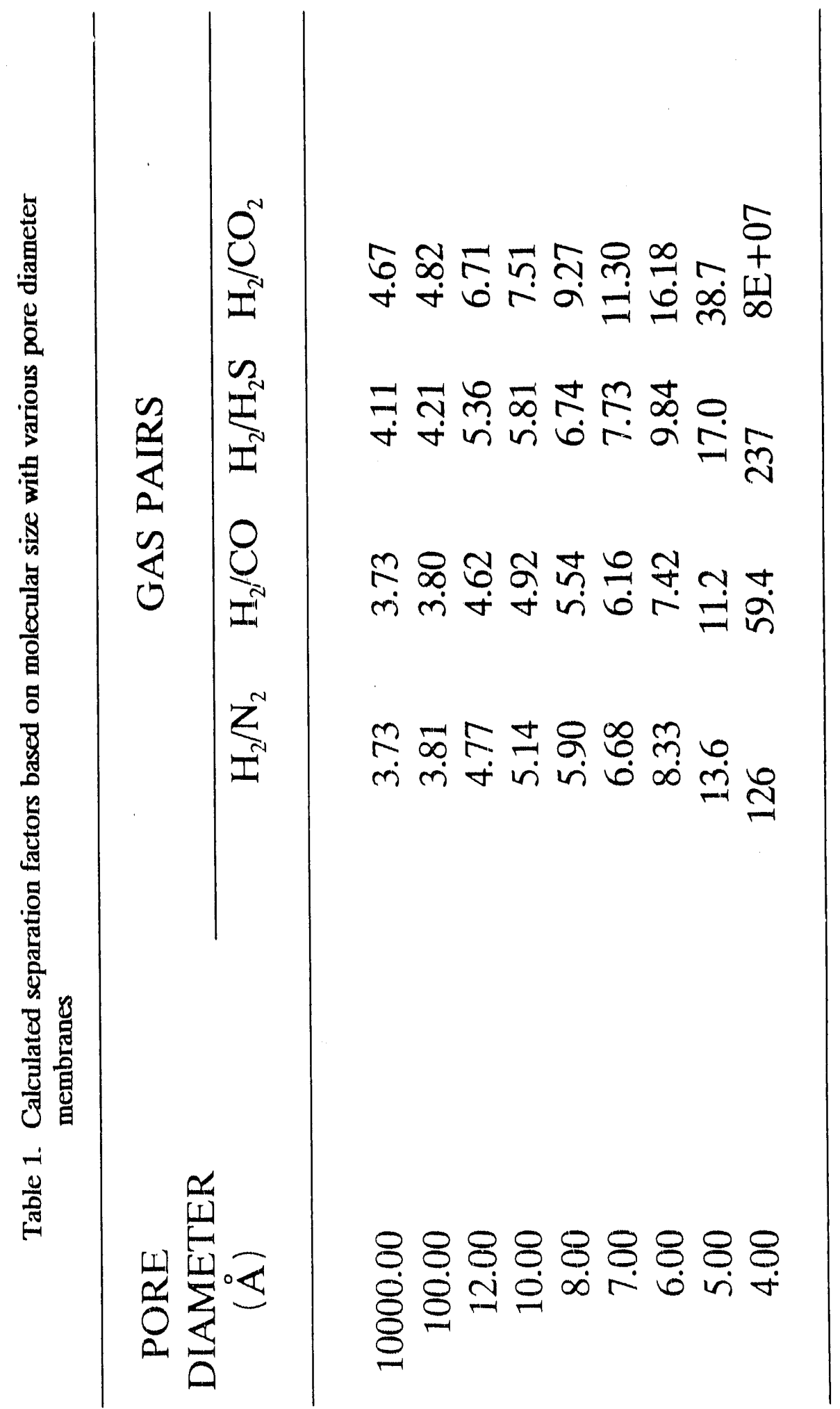


decrease, resulting in a lower gas flow thruugh the membrane. So these two factors much be balanced before a practical, efficient membrane can be developed. Nevertheless, this illustrates the potential advantage of smaller pore sizes. Development of improved inorganic membranes with these properties could provide significant advantages for gas separations. Preliminary calculations were made to estimate the size of a conceptual commercial membrane separation unit to recover, for example, $90 \%$ of the hydrogen in a typical gas mixture produced in an entrained-bed coal gasifier. Assuming a very high separation factor for hydrogen relative to the other gases present in the raw synthesis gas, and based on a hydrogen permeability of $0.01 \mathrm{~cm}^{3} / \mathrm{cm}^{2} \cdot \mathrm{s} \cdot(\mathrm{cm} \mathrm{Hg})$, the calculation showed that to recover $1.8 \mathrm{~kg}-\mathrm{mol} / \mathrm{s}(\sim 14,000 \mathrm{lb}-\mathrm{mol} / \mathrm{h})$ would require $1580 \mathrm{~m}^{2}\left(\sim 17,000 \mathrm{ft}^{2}\right)$ of membrane surface area. This would translate into a membrane separation unit that is similar in design to a conventional shell-and-tube heat exchanger that is $3 \mathrm{~m}(10 \mathrm{ft})$ in diameter by $3.7 \mathrm{~m}(12 \mathrm{ft})$ long.

\section{RESULTS}

\subsection{MEMBRANE FABRICATION}

Several materials, such as alumina, zirconia, and titania, were identified as potential membrane materials. Both alumina and zirconia membranes were prepared. However, alumina was selected as the primary material for fabricating the membranes. The selection of alumina was based on several factors, including thermal and mechanical stability, chemical stability in the expected gas environment, and fabricability into appropriate tubular configurations. Over 200 of these alumina membrane tubes have been fabricated. The tubes have an outside diameter of $\sim 9 \mathrm{~mm}$ and a wall thickness of $\sim 0.5 \mathrm{~mm}$. Fabrication of the 
membranes involves the use of classified technology and consequently cannot be discussed in this report.

During the course of the program, significant improvements were made in fabricating alumina membranes. The average pore radius of the membranes was reduced from $\sim 150 \AA$ for the initial membranes to $<10 \AA$ for the latest membranes. This pore-size reduction was accomplished while maintaining an acceptable membrane permeability. A relatively high leak flow was detected in some of the earlier membranes. It was determined that this leak flow was caused by small cracks at the ends of the tubes, which resulted during the handling and testing procedures. Metal ferrules were attached to the ends of the tubes to facilitate the handling and testing and to alleviate the cracking problem.

For ambient temperature measurements, metal ferrules were attached to the ends of the membrane tubes with epoxy. However, for higher temperature tests, other sealing methods had to be developed for attaching the membranes to the test system. First, we attempted to braze the alumina membrane to ferrules made of 446 stainless steel, which provides good sulfidation resistance as well as relatively low coefficient of thermal expansion. However, during thermal cycle tests, some of the assemblies developed leaks resulting from crack formations in the alumina membranes. To minimize stresses on the alumina membrane, a ring of niobium, which has a thermal expansion coefficient similar to alumina, was joined to the alumina tube, and a stainless steel ferrule was joined to the niobium ring. An active metal brazing technique was used to join the three components in a single brazing cycle. A silver/copper braze material containing titanium as the active metal was used to form a "butttype" joint. The membranes were then attached to the test system through the ferrules using compression fittings adapted to autoclave fittings. Test assemblies that were fabricated in this 
manner remained leak-tight following thermal cycling to $1000^{\circ} \mathrm{F}$ and back to room temperature.

A screening procedure that used air permeability, as well as pore-size distribution measurements, was used to evaluate the membrane samples. Results from these tests were used as a guide to determine the effects of various fabrication parameters on the membrane product and to decide which membranes should be further evaluated.

\subsection{MEMBRANE CHARACTERIZATION}

\subsubsection{Pore-Size Distribution}

A dynamic, flow-weighted pore-size distribution test, developed at the Oak Ridge K-25 Site, ${ }^{24}$ was used to measure the pore-size distributions of the tubular alumina membranes. Such flow-weighted pore-size distributions can be measured by using a binary mixture of a condensible gas (carbon tetrachloride) and a noncondensible gas (nitrogen). As the absolute pressure of the mixture, and, therefore, the pressure of the condensible gas, is increased incrementally, the condensible gas is capillary condensed in progressively larger pores. The condensed liquid fills and plugs the pores of the material so that the noncondensible gas cannot flow through these pores. The gas flow rate is measured at each change in pressure. The pore size and flow rate are corrected for adsorption of the carbon tetrachloride on the surface of the membrane. Then the corrected flow rate is plotted against the corrected pore radius to give a cumulative flow-weighted pore-size distribution.

The pore-size distributions of experimental alumina membranes were measured using the dynamic pore-size measurement technique. An example of the pore-size distribution of an carly alumina membrane is shown in Fig. 3. As shown in the figure, these carly 


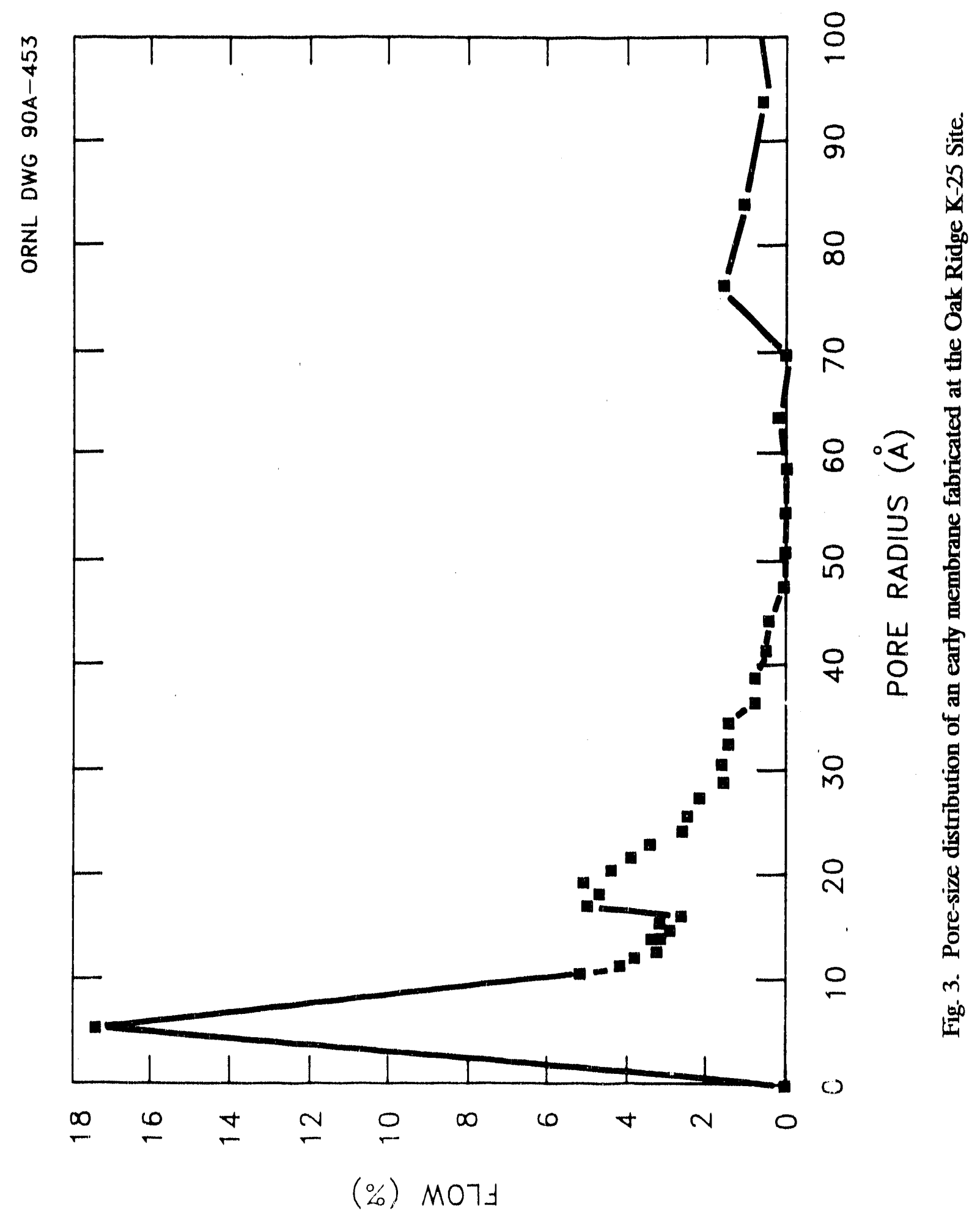


membranes contained some larger pores, and $<20 \%$ of the gas flow was through pores with a radius of $<10 \AA$. Several process improvements were incorporated to reduce pore size and to improve the pore-size distribution. The improvements can be seen in the example shown in Fig. 4. The mean pore radius of the improved membrane is $<10 \AA$, with essentially no pores with a radius larger than $20 \AA$. In these improved membranes, over $60 \%$ of the gas llow is through pores with a radius $<10 \AA$.

Some commercially available porous materials were also obtained and evaluated. By our measurements, these materials had an average pore radius of $\sim 20 \AA$.

\subsubsection{Burst Strength}

Hydrostatic tests were made on six of the tubular membranes to determine their burst strength at room temperature. The burst strength at $1000^{\circ} \mathrm{F}$ is expected to be $\sim 90 \%$ of the value determined at room temperature. As shown in Table 2, the burst strength values ranged from 800 to $1600 \mathrm{psig}$, with a mean value of about $1300 \mathrm{psig}$. Based on these results, it was concluded that the membranes with this configuration should operate well in gasifiers up to pressures of 600 psig, which was the initial goal.

\subsection{MEMBRANE TEST SYSTEM}

A test apparatus for measuring the gas permeabilitics of membranes at high temperatures (up to $500^{\circ} \mathrm{C}$ ) and pressures (up to $4 \mathrm{MPa}$ ) was designed and constructed. For safety reasons, the total gas flow was restricted to $1.0 \mathrm{~L} / \mathrm{min}$.

A flow diagram of the apparatus is shown in Fig 5. Gases are supplied from cylinders through high-pressure regulators and an associated manifold. Pressures are set by 


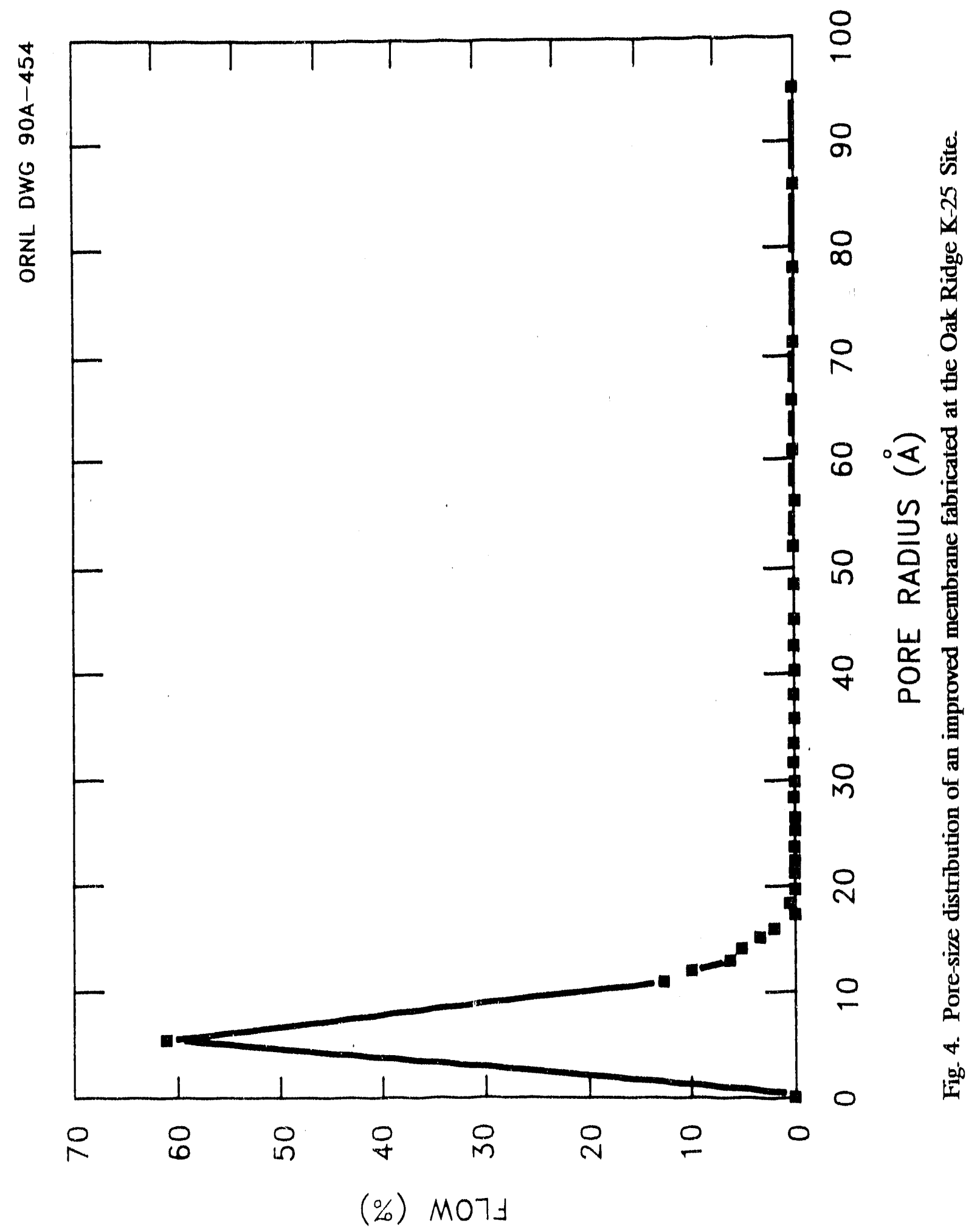


Table 2. Burst strength of typical tubular alumina membranes

\begin{tabular}{cc}
\hline Membrane Sample & $\begin{array}{c}\text { Rupture pressure } \\
\text { (psig) }\end{array}$ \\
\hline 1 & 1450 \\
2 & 1350 \\
3 & 820 \\
4 & $1500)$ \\
5 & 1300 \\
6 & 1600 \\
Mean & 1340 \\
Standard Deviation & 275 \\
\hline
\end{tabular}

pressure-control valves, and gas flows are neasured with differential pressure transmitters. Pressures are measured with pneumatic pressure transmitters connected to chart recorders. Pressures are measured upstream of the membrane, downstream of the membrane, and on the permeate side of the membrane. Research control valves, located in the feed, ralfinate, and permeate streams, can be used to control gas pressures and flows. Differential pressure $(\mathrm{d} / \mathrm{p})$ cells with integral orifices are used to measure feed, permeate, and raffinate gas flows. The $\mathrm{d} / \mathrm{p}$ eells are connected to controller/recorders. The $\mathrm{d} / \mathrm{p}$ eells in the feed and raffinate gas streams have 0.010 -in. orifices with an output range of 0 to $20 \mathrm{in.}$ of water; the permeate $\mathrm{d} / \mathrm{p}$ cell has a 0.007 -in. orifice with an output range of 0 to $5 \mathrm{in}$. of water.

The gases are preheated in a threc-zone tube furnace, which also houses the membrane assembly. Tempera ares are measured with thermocouples, and exit gases are cooled with heat exchangers, if necessary, and analyzed by gas chromatography.

Shutolf valves are operated by air-controlled actuators, supplied through solenoidoperated valves. The recorder/controllers, thermocouple readouts, and valve switches are 


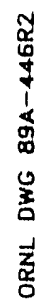

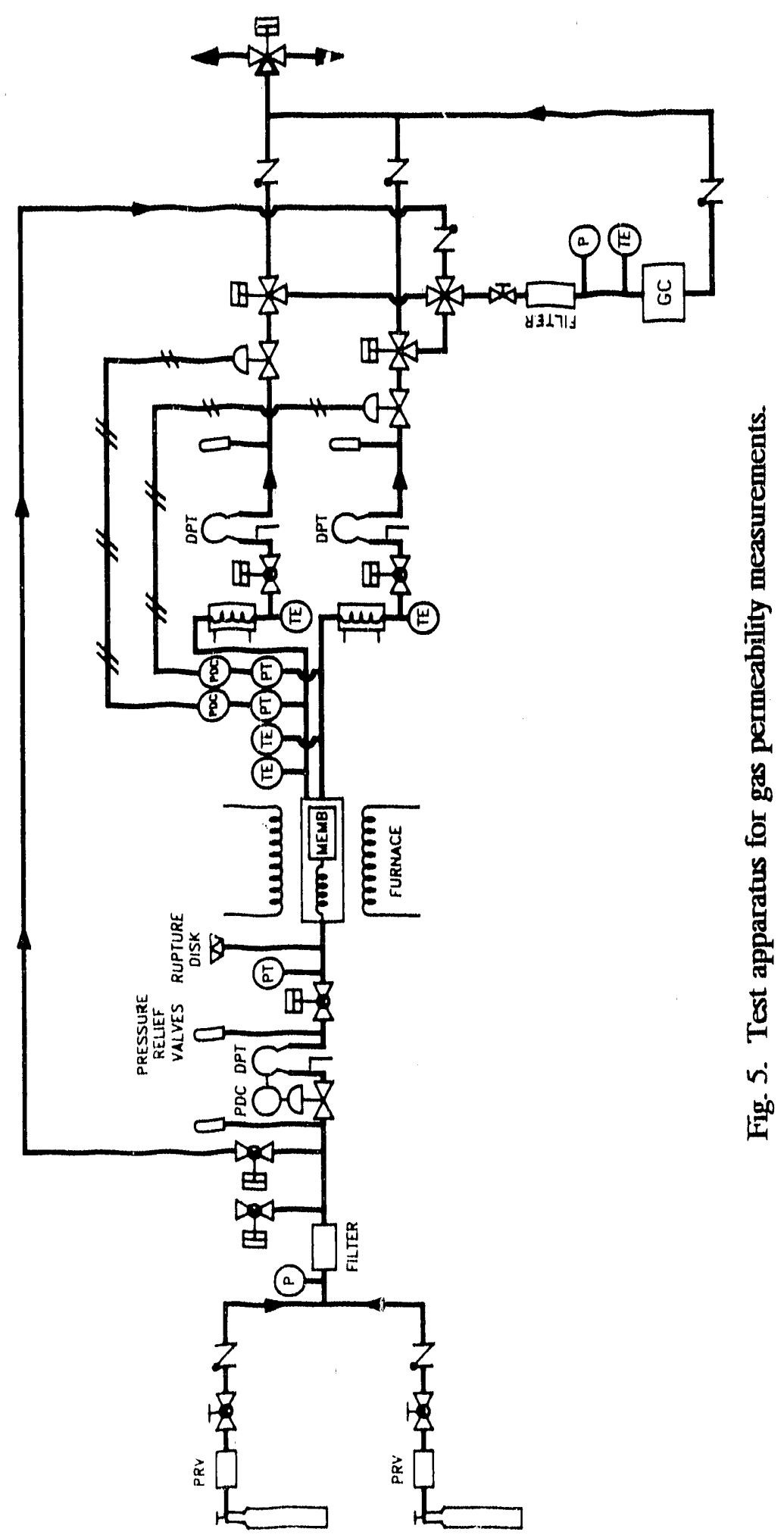


installed in a separate instrument cabinet. The apparatus is contained in a floor-standing hood (Fig. 6).

The feed and raffinate $\mathrm{d} / \mathrm{p}$ cells were calibrated by measuring the flows of helium and nitrogen at different pressu:es, using a mass flowmeter and a bubble flow meter equipped with an electronic timer. A modified Darcy equation for calculating noncritical flow through an orifice ${ }^{25}$ was used to calculate the gas flows at other meastired pressures and differential pressures across the $\mathrm{d} / \mathrm{p}$ cell.

The errors associated with gas flow calculations, chart recorder readings, etc., were evaluated to better define the limitations of the test system. The readability of the pressure indicators and $\mathrm{d} / \mathrm{p}$ cell outputs was $\sim 0.5 \%$. In calculating gas flows, the readability limitations result in an error of $\pm 0.65 \%$ at full scale, increasing to $\pm 5 \%$ at $10 \%$ of full scale. The resultant error in calculating gas flows was estimated to be $\sim 5.5 \%$ at the higher flows and pressures.

\subsection{PERMEABILITY MEASUREMENTS}

Permeability is defined as the volume of gas flow per unit of time for a given membrane area and pressure difference across the membrane. The membrane thickness is not a variable in this definition. The units for gas permeability are cubic centimeters of gas flow per minute per square centimeler of membrane area per centimeter-of-mercury pressure differential across the membrane.

Several alumina membranes having pore radii ranging from $\sim 7$ to $22 \AA$ were labricated, and their permeabilities were measured in different pressure ranges using pure gases, including $\mathrm{He}, \mathrm{N}_{2}, \mathrm{CO}_{2}$, and $\mathrm{SF}_{6}$. Measurements were made on selected membranes at 


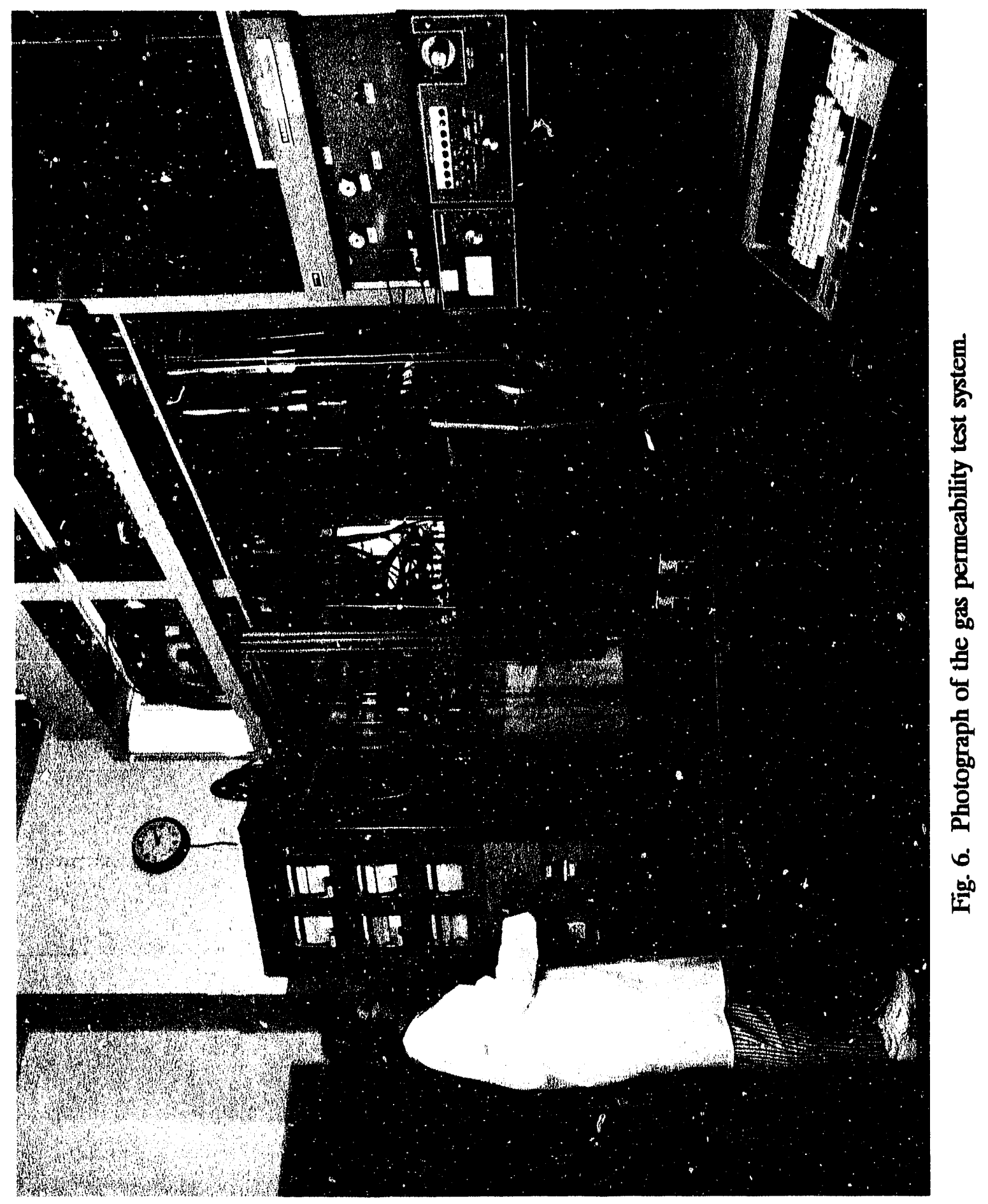


higher temperatures and pressures using helium and nitrogen. Several membranes were tested for separating gas mixtures simulating a coal gasifier product gas.

\subsection{ROOM TEMPERATURE TESTS}

A series of six different membranes (Series A), having different pore sizes ranging from $\sim 9$ to $22 \AA$ pore radius, was initially characterized. The permeabilities of the membranes were measured at room temperature using pure gases: $\mathrm{He}, \mathrm{N}_{2}, \mathrm{CO}_{2}, \mathrm{SF}_{6}$, and air. Typical results from these measurements are illustrated in Fig. 7, in which the permeability is plotted against the pressure summation, i.e., the sum of the feed and permeate pressures. The permeability of the gases did not vary appreciably with pressure for the gases and pressure ranges that were tested. In general, the order of permeability was $\mathrm{He}>>$ air $\geq \mathrm{N}_{2} \geq \mathrm{CO}_{2}>\mathrm{SF}_{6}$. The data for the series of membranes are summarized in Fig. 8, in which the calculated separation factors (ratio of permeabilities) for helium/nitrogen and helium/carbon dioxide are plotted versus the average pore size for the different membranes. Also shown in Fig. 8 are the calculated ideal separation factors, assuming a Knudsen gas transport mechanism. It is apparent that other gas transport mechanisms play a role, particularly in the case of carbon dioxide. The enhanced permeability of carbon dioxide, probably due to adsorption and surface diffusion, reduces the helium/carbon dioxide separation factor. The helium/nitrogen separation factor is also reduced somewhat as the membrane pore size decreases.

Figure 9 shows an example of similar types of data obtained for another series (Series B) of alumina membranes. Again, helium and sitrogen exhibit behavior more characteristic of predicted Knudsen transport, while other gas transport mechanisms, probably due to surface adsorption or other membrane interaction, play a larger role in carbon dioxide 


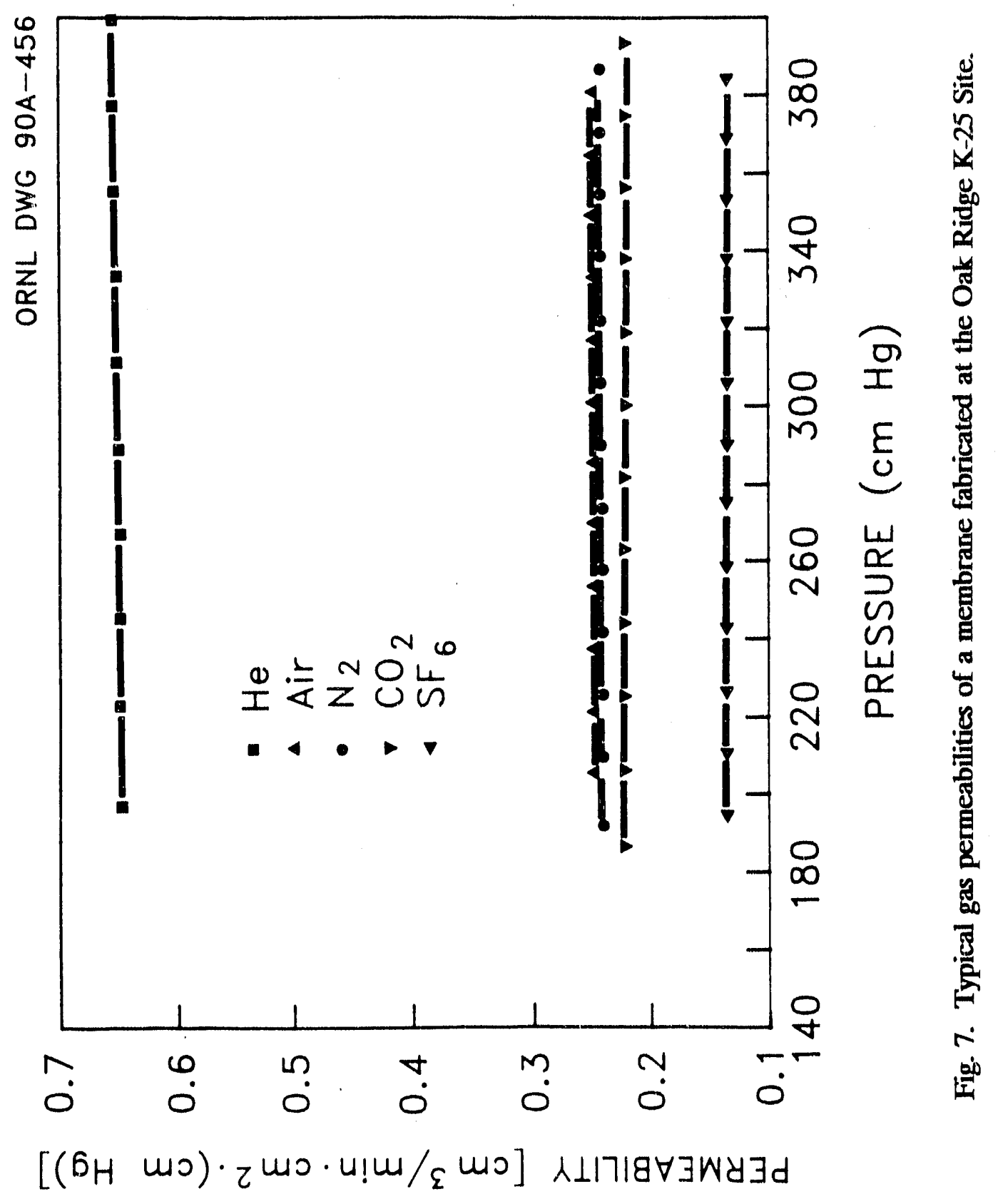




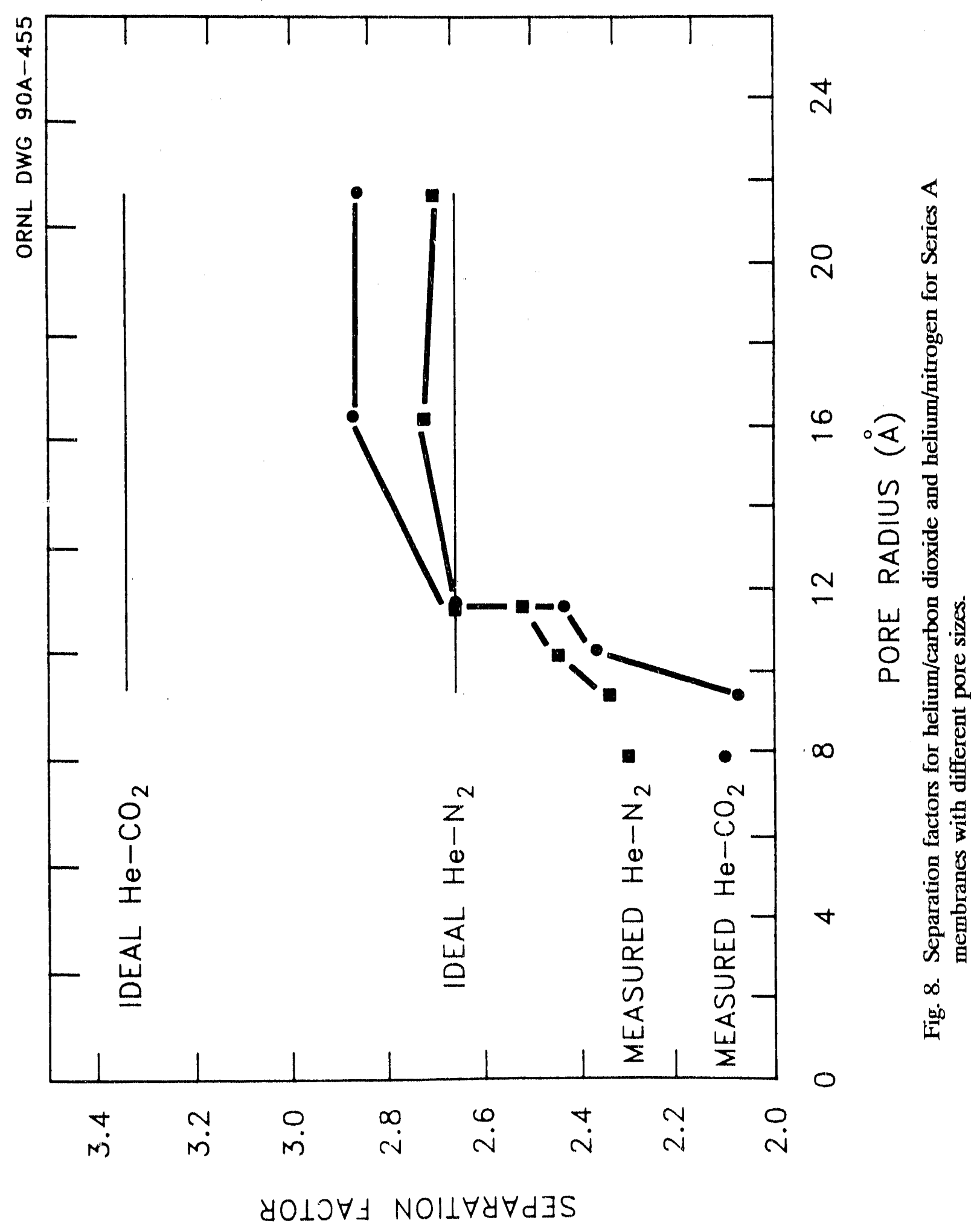




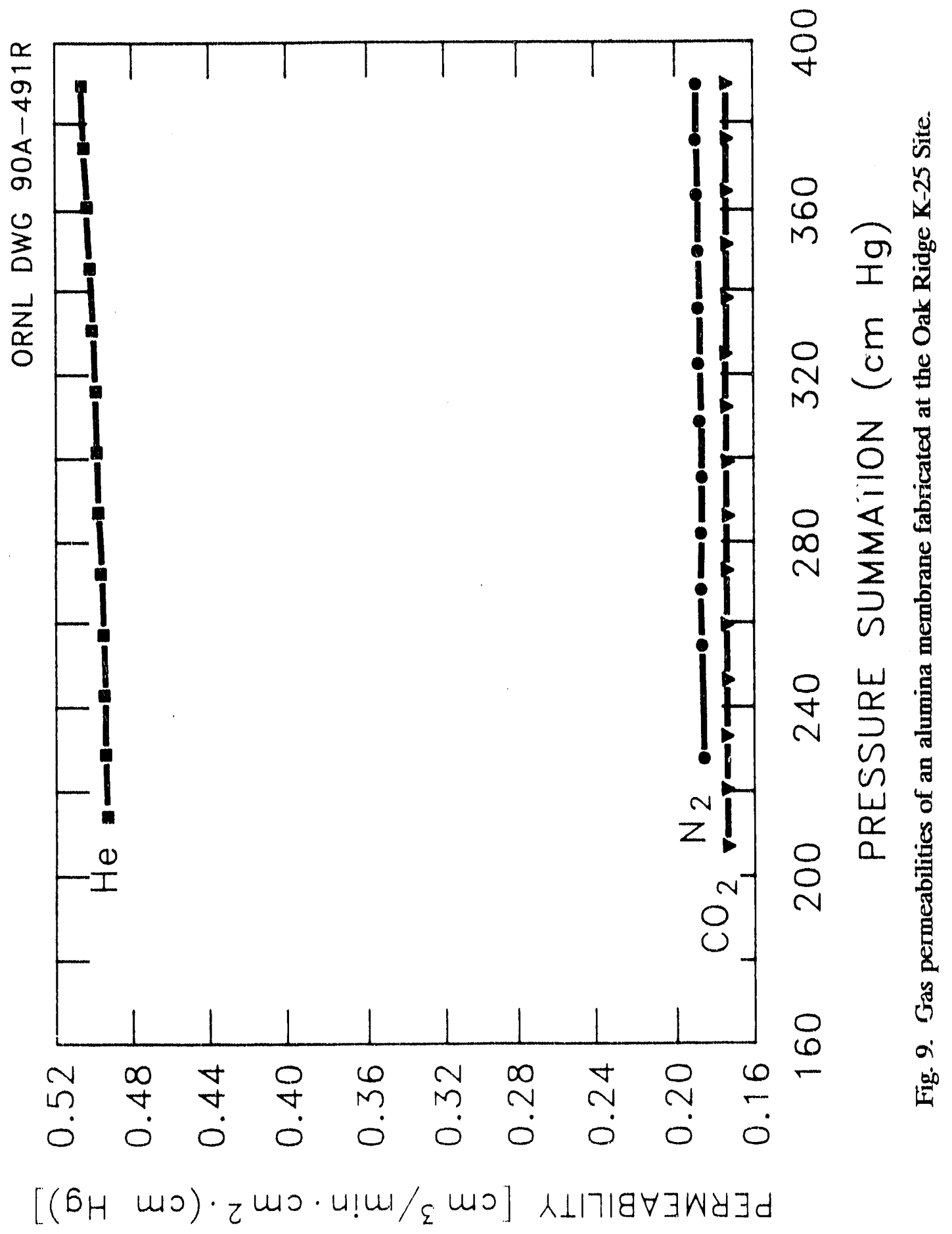


transport. Figure 10 summarizes the permeability data for the series of seven membranes having pore radii ranging from $\sim 7$ to $18 \AA$. Figures 8 and 10 are unique plots in that separation factors were determined for a series of similar membranes having different pore sizes in the range below $25 \AA$ pore radius.

\subsection{HIGH-PRESSURE TESTS}

Gas permeability measurement were also made at higher pressures with helium, nitrogen, and carbon dioxide, using the test apparatus described in Fig. 5. These measurements were made at room temperature $\left(20^{\circ} \mathrm{C}\right)$ in the feed-gas pressure rarage of 50 to $150 \mathrm{psi}(0.34$ to $1.02 \mathrm{MPa})$. As seen in Fig. 11, the permeability behavior of these gases in this pressure range is qualitatively similar to the results obtained in the lower pressure range.

Nitrogen and helium permeabilities of another membrane sample were measured up to a feed gas pressure of $589 \mathrm{psi}(4.06 \mathrm{MPa})$ (Fig. 12). The relative gas permeabilities correlate qualitatively with a Knudsen flow mechanism; however, other gas transport mechanisms may also play a role when a pressure gradient is applied across the membrane. ${ }^{26,27}$ Laminar flow may occur when the mean free path of the gas molecules is much smaller tian the mean pore radius of the porous membrane. Surface diffusion can occur when the gas molecules are adsorbed on the surface of the membrane and move along the surface. The increase in permeability with increasing pressure, particularly in Fig. 12, may be partly a result of these effects. 


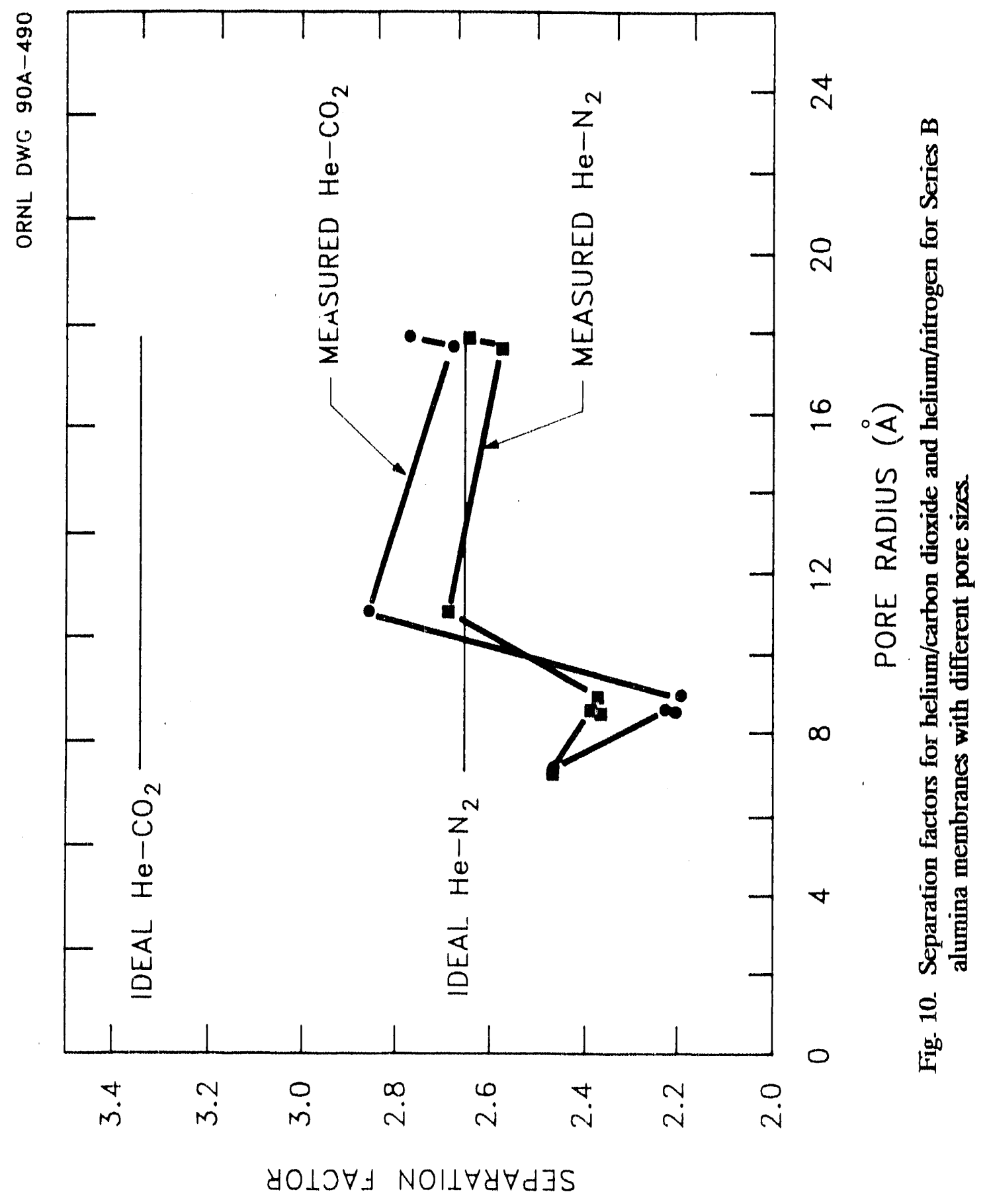




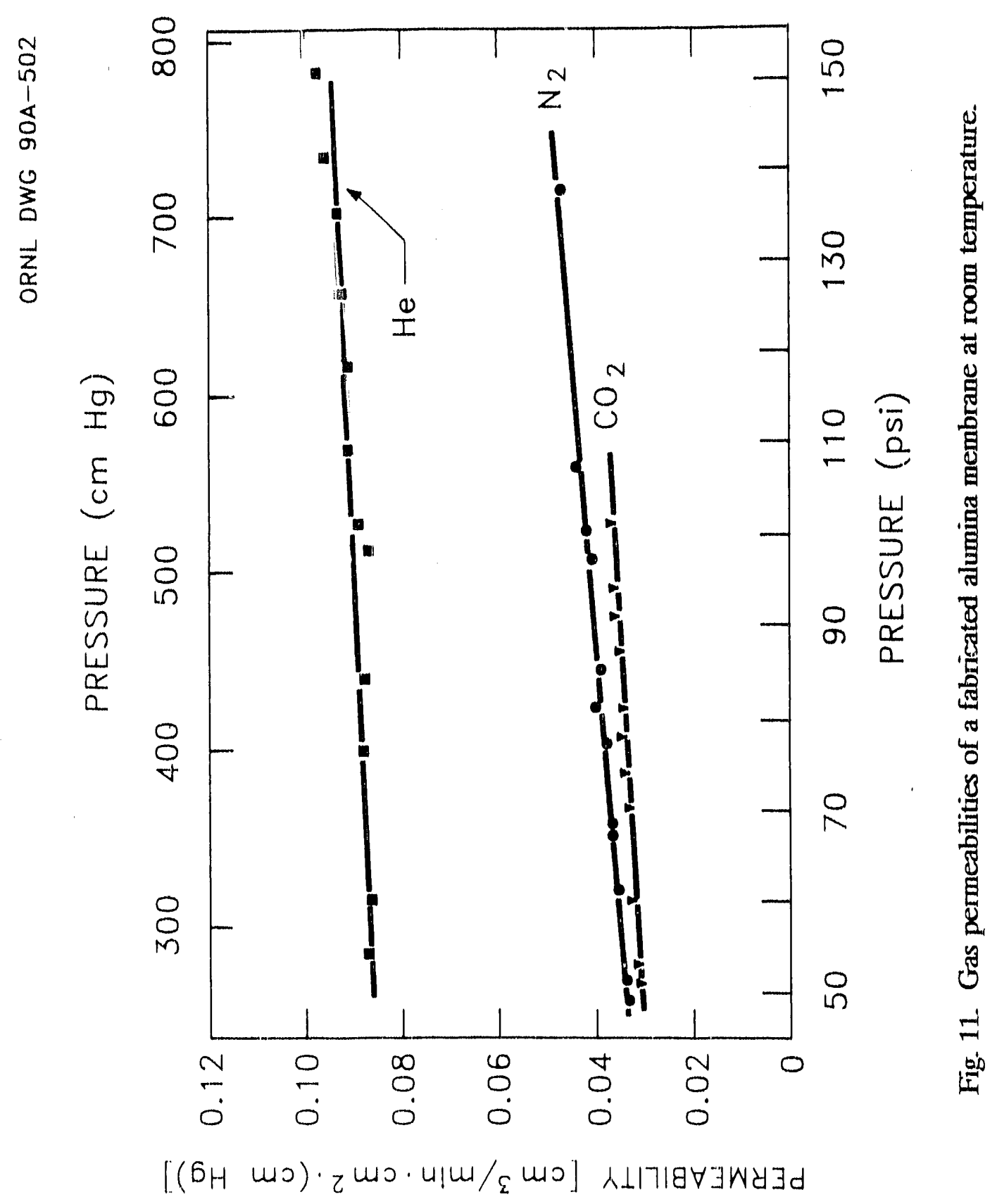




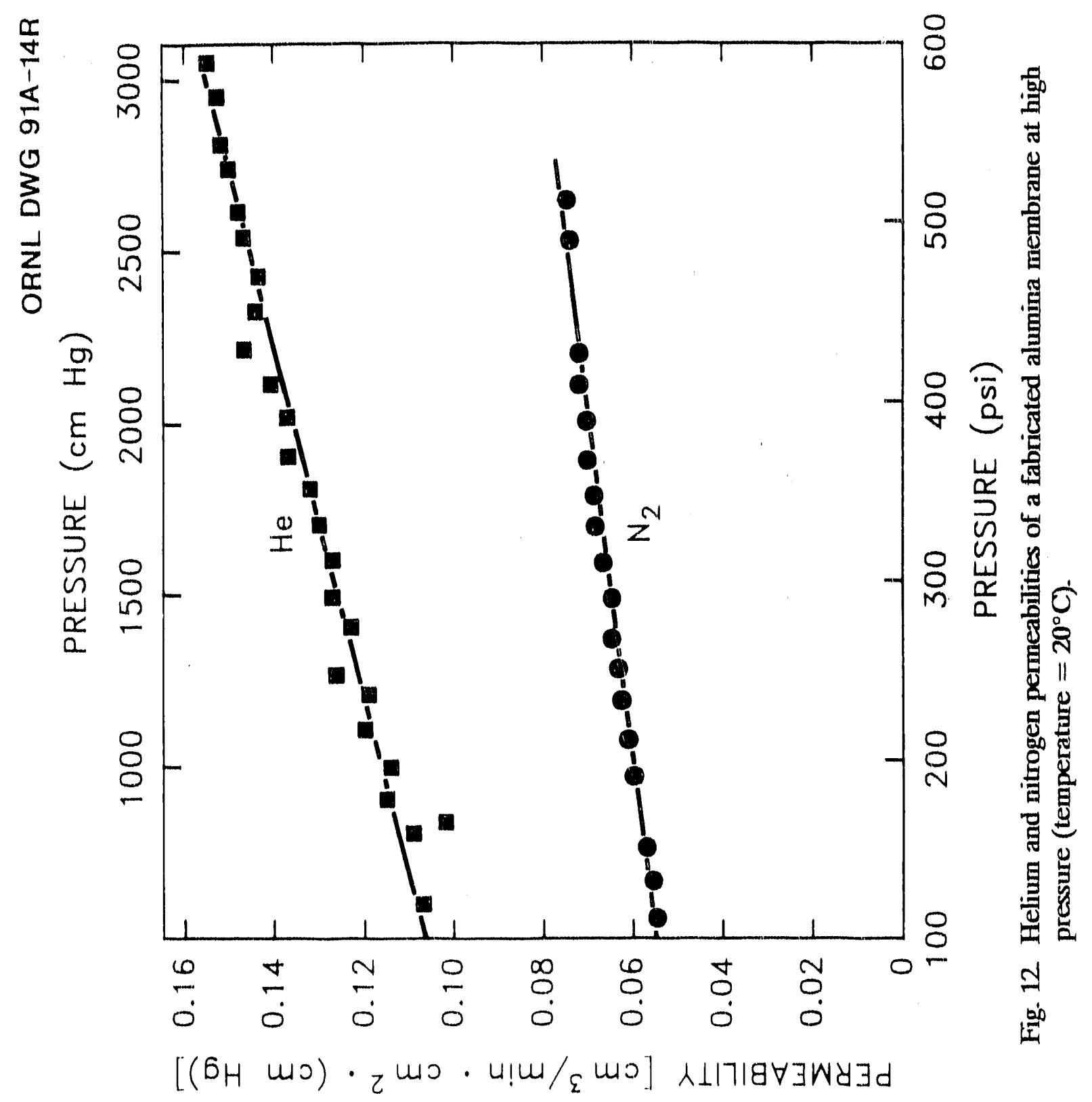




\subsection{PERMEABILITY AT HIGHER PERMEATE GAS PRESSURES}

In the permeability measurements described previously, the permeate gas was vented to the atmosphere, so the permeate pressure was constant (atmospheric). The gas permeabilitics of several fabricated alumina membranes were measured using a modified membrane assembly in which the permeate gas was contained and the gas pressure on both the permeate side and the feed side of the membrane could be varied. These measurements simulate a more practical situation in which the membrane would be operated at a high fieed pressure and the permeate gas would also be maintained at pressures above atmospheric; the differential pressures across the membrane could be varied. The membrane assembly contained an epoxy seal, so tests were made at ambient temperature and at relatively low pressures.

The results of these tests are summarized in Table 3 for three of the membrane samples. The average permeabilities of pure helium and pure nitrogen were determined over a range of feed gas pressures and differential pressures across the membranes. The average permeability of the membranes increased significantly (i.e., from 0.024 to 0.25 $\mathrm{cm}^{3} / \mathrm{min} \cdot \mathrm{cm}^{2} \cdot(\mathrm{cm} \mathrm{Hg})$ for nitrogen, and from 0.038 to $0.54 \mathrm{~cm}^{3} / \mathrm{min} \cdot \mathrm{cm}^{2} \cdot(\mathrm{cm} \mathrm{Hg})$ for helium) as the membranes were improved, while the calculated separation factors (ratio of pure gas permeabilities) were maintained and also increased from 1.6 to 2.2 .

\subsection{PERMEABILITY MEASUREMENTS AT HIGHER TEMPERATURES}

The pure gas permeabilities of helium and nitrogen were measured using a fabricated alumina membrane at $20\left(0^{\circ} \mathrm{C}\right.$ and $50(0)^{\circ} \mathrm{C}$. For comparison, the gas flows were calculated for $20^{\circ} \mathrm{C}$. For the higher temperature tests, the membrane sample was attached to stainless steel ferrules through a niobium spacer using a brazing tecinnique as described previously. The gas 
'Table 3. Summary of gas permeability measurements at higher permeate gas pressures

\begin{tabular}{|c|c|c|c|}
\hline \multirow[t]{2}{*}{ 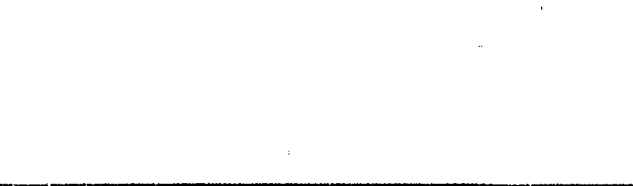 } & \multicolumn{3}{|c|}{ Membrane Sample } \\
\hline & 1 & 2 & 3 \\
\hline Membrane Area $\left(\mathrm{cm}^{2}\right)$ & 11,9 & 6.3 & 6.4 \\
\hline \multicolumn{4}{|l|}{ Nitrogen } \\
\hline Feed pressure (psig) & $36-158$ & $58-124$ & 39. 74 \\
\hline Permeate pressure (psig) & $16-68$ & $45-80$ & $33-56$ \\
\hline $\begin{array}{l}\text { Pressure differential across } \\
\text { membrane (psi) }\end{array}$ & 20- 91 & $13-44$ & $6-18$ \\
\hline $\begin{array}{l}\text { Average } j \text { ermeability } \\
\left(\mathrm{cm}^{3} / \mathrm{min} \mathrm{cm}^{2} \cdot(\mathrm{cm} \mathrm{Hg})\right.\end{array}$ & 0.0237 & 0.169 & 0.245 \\
\hline \multicolumn{4}{|l|}{ Helium } \\
\hline Feed pressure (psig) & $43-170$ & $50-113$ & $48-103$ \\
\hline Permeate pressure (psig) & $20-78$ & $43-87$ & $41-86$ \\
\hline $\begin{array}{l}\text { Pressure differential across } \\
\text { membrane (psi) }\end{array}$ & $23-91$ & $7-26$ & 7- 16 \\
\hline $\begin{array}{l}\text { Average permeability } \\
\left(\mathrm{cm}^{3} / \mathrm{min} \mathrm{cm}^{2} \cdot(\mathrm{cm} \mathrm{Hg})\right.\end{array}$ & 0.038 & 0.329 & 0.537 \\
\hline Calculated separation factor $\left(\mathrm{He} / \mathrm{N}_{2}\right)$ & 1.6 & 1.9 & 2.2 \\
\hline
\end{tabular}

flows through the membrane were measured at different feed gas pressures; the permeate gas was vented to the atmosphere. The results were calculated as the gas flux per unit pressure differential across the membrane and refereneed to a temperature of $20^{\circ} \mathrm{C}$. The measurements were made sequentially at $20^{\circ}, 200^{\circ}$, and $500^{\circ} \mathrm{C}$. The membrane was then cooled back to $20^{\circ} \mathrm{C}$, and the measurements were repeated. Table 4 shows the pressure ranges, the average gas fluxes, and the calculated separation factors based on the ratio of the average gas fluxes of helium and nitrogen, at $20^{\circ} \mathrm{C}$ (before licating), $2000^{\circ} \mathrm{C}, 50\left(0^{\circ} \mathrm{C}\right.$, and again 
at $20^{\circ} \mathrm{C}$ (afte. heating). The helium flux increased as the temperature was increased. The nitrogen flux decreased by about $18 \%$ when the membranc was heated to $200^{\circ} \mathrm{C}$, with no significant change when heated further to $5000^{\circ} \mathrm{C}$. The fluxes of both gases were significantly higher at $20^{\circ} \mathrm{C}$ after the membrane had been heated to $5000^{\circ} \mathrm{C}$. The calculated separation factors incrialsed as the temperature was increased, reaching 2.66 at $500^{\circ} \mathrm{C}$. The ideal Knudsen separation factor is 2.65 .

These results indicate that: (1) heating removes water and other adsorbed materials from the pores of the membrane, resulting in a higher flow of both gases after the membrane

Table 4. Comparison of gas fluxes through an alumina membrane at higher temperatures

\begin{tabular}{|c|c|c|c|c|}
\hline & \multicolumn{4}{|c|}{ Temperature $\left({ }^{\circ} \mathrm{C}\right)$} \\
\hline & $20^{\mathrm{a}}$ & 200 & 500 & $200^{b}$ \\
\hline \multicolumn{5}{|l|}{ Helium } \\
\hline Prcssurc range (psig) & $35-6.3$ & $33-66$ & $31-61$ & $29-55$ \\
\hline $\begin{array}{l}\text { Avg. Flux } \\
\left(\mathrm{cm}^{3} / \mathrm{min} \cdot \mathrm{psi}\right)\end{array}$ & 7.82 & 8.23 & 9.78 & 11.7 \\
\hline \multicolumn{5}{|l|}{ Nitrogen } \\
\hline Pressure range (psig) & 34.81 & $35-87$ & 34.89 & 29.73 \\
\hline $\begin{array}{l}\text { Avg. Flux } \\
\left(\mathrm{cm}^{3} / \mathrm{min} \cdot \mathrm{psi}\right)\end{array}$ & 4.42 & 3.62 & 3.67 & 6.21 \\
\hline $\begin{array}{l}\text { Calculated separation factor } \\
\qquad\left(\mathrm{He} / \mathrm{N}_{2}\right)\end{array}$ & 1.77 & 2.27 & 2.66 & 1.88 \\
\hline
\end{tabular}

"Before heating.

"Alter heating. 
was heated; (2) higher surface adsorption of nitros at $20{ }^{\circ} \mathrm{C}$ results in more surface flow and a lower separation factor; (3) surface adsorption is negligible at higher temperatures, and the separation factors approach the ideal value expected from Knudsen diffusion.

\subsection{SEPARA'TION OF GAS MIXTURES}

Two different mixtures of gases were used to simulate coal gasifier synthesis gas products. The compositions of the two mixtures obtained from Matheson Gas Company are shown in Table 5. One of the gas mixtures contained $\mathrm{H}_{2}, \mathrm{CO}, \mathrm{CO}_{2}$, and $\mathrm{CH}_{4}$; the second mixture contained these gases, along with nitrogen. The alumina membranes were tested for their ability to separate hydrogen from the gas mixtures. The membranes were tested at different feed gas pressures, ratios of permeate to residue gas flows, and differential pressures across the membranes. For these tests, the membrane assembly contained epoxy scals, so the tests were made at room temperature. The feed, raffinate, and permeate gas streams were analyzed by gas chromatography. Typically, the pressure on the feed side of the membrane ranged from 65 to 75 psig, and the pormeate pressure ranged from $\sim 23$ to $29 \mathrm{psig}$. The permeate gas was enriched in hydrogen, primarily at the expense of carbon dioxide (reduced carbon dioxide content).

Figure 1.3 compares the chromatograms of the permeate and residue gases from one lest using gas mixture 2. In this test, the feed gas pressure was $66 \mathrm{psig}$, and the permeate pressure was $5($ ) psig for a diflerential pressure across the membrane of 16 psi. The gas flows were adjusted so that $\sim 15 \%$ of the gas was allowed to flow through the membrane as permeate. It can be seen that qualitatively the relative amount of hydrogen compared to carbon dioxide is higher in the permeate gas and lower in the residue gas. In tests similar to 
Table 5. Composition of simulated coal gasificr gas nixtures

\begin{tabular}{lcc}
\hline & \multicolumn{2}{c}{ Content (\%) } \\
\cline { 2 - 3 } Gas & Mixiture 1 & Mixture 2 \\
\hline & & \\
Hydrogen & 35.30 & 19.85 \\
Carbon dioxide & 19.86 & 5.01 \\
Carbon monoxide & 35.54 & 19.97 \\
Methane & 9.50 & 4.99 \\
Nitrogen & $\ldots . .-$ & 50.18 \\
\hline
\end{tabular}

this, the hydrogen content in the permeate gas compared to the feed gas increased from $35.3 \%$ to $45.5 \%$ lor mixture 1 and from $19.85 \%$ to $24.5 \%$ for mixture 2 .

\section{SUMMARY AND DISCUSSION}

Porous tubular alumina membranes with a diameter of $\sim 9 \mathrm{~mm}$ and a wall thickness of $\sim 0.5 \mathrm{~mm}$, having pore radii ranging from $<10 \AA$ to $150 \AA$, have been labricated and tested. These membranes are capable of withstanding $>600)$ psi $(4 \mathrm{MPa})$ pressure and opcrating up to $1000^{\circ} \mathrm{F}$.

The permeability of pure gases, including $\mathrm{He}, \mathrm{N}_{2}, \mathrm{CO}_{2}$, and $\mathrm{SF}_{6}$, and the separation of gas mixlures containing $\mathrm{H}_{2}, \mathrm{CO}, \mathrm{CO}_{2}, \mathrm{~N}_{2}$, and $\mathrm{CH}_{4}$ were measured over a range of pressures and temperatures. The primary mechanism of gas transport across the membranes appears to be Knudsen diffusion. Consequently, the separation factors for the gases are determined, and limited, by their relative molecular weights. When the membranes were 


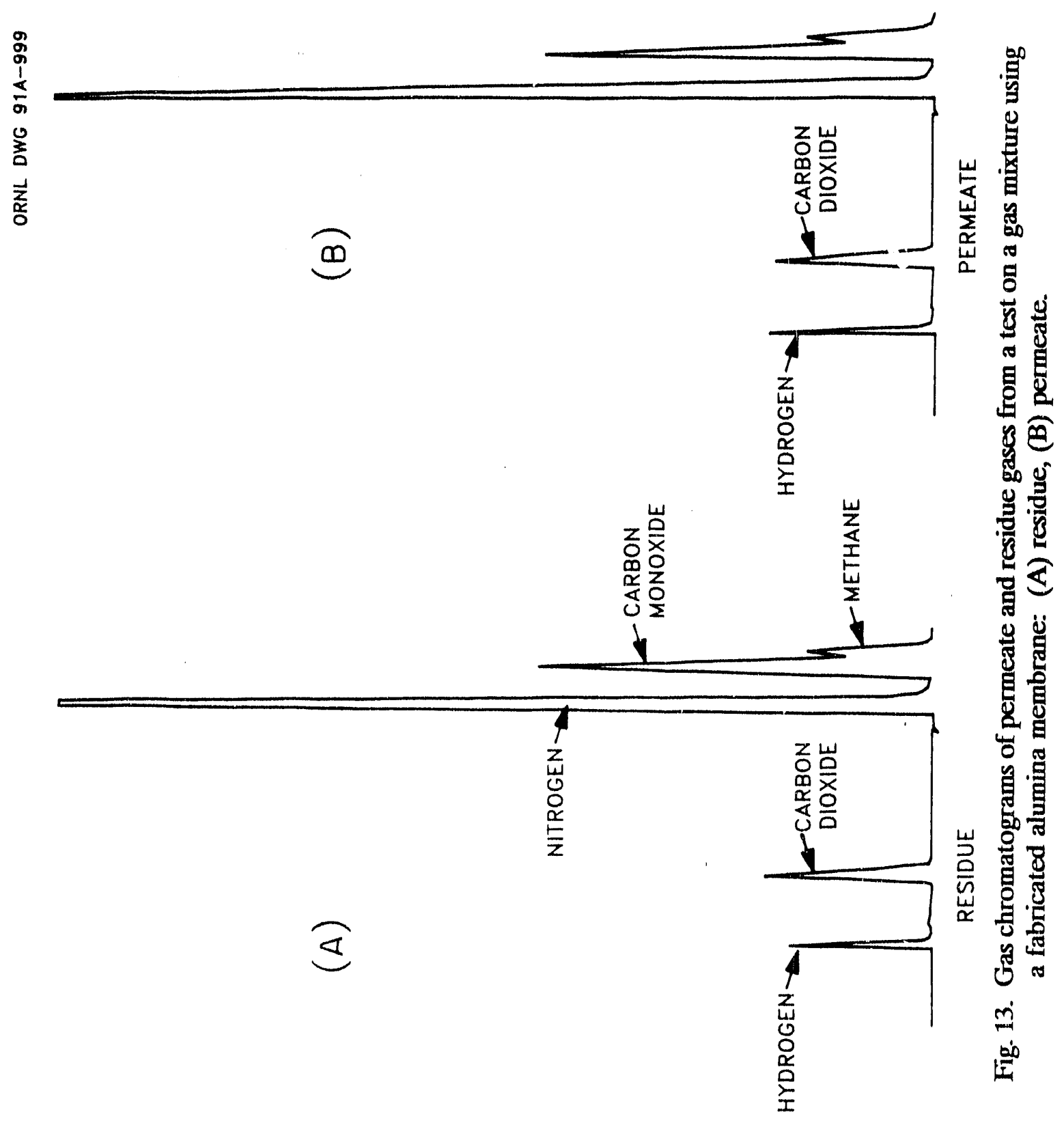


tested for separating gas mixtures, the permeate gas was enriched in hydrogen, primarily at the expense of carbon dioxide (reduced carbon dioxide in the permeate and increasud carbon dioxide in the residue gas).

When a "Knudsen flow" gas transport mechanism is operating, the ideal separation factors are $<10$ for gases of general interest. For example, the calculated separation factors for hydrogen/nitrogen and hydrogen/carbon diovide are 3.73 and 4.67 , respectively. Separation factors $>10$ would be preferred for practical and economical process applications. Consequently, it will be necessary to take advantage of other gas transport mechanisms to improve separation factors. One approach is to develop membranes with smaller pores to take advantage of a molecular sieving effect. We are continuing to work in that direction. Mathematical models ${ }^{28}$ indicate that membranes with radii $<3 \AA$ will be required. The measurement of pore sizes in this range becomes very difficult. These pores approach the size of crystal lattice dimensions, and the gas permeability would be expected to decrease significantly. Other gas transport mechanisms such as adsorption and surface diffusion may become more important.

Another approach that might be used to improve the gas separation factor is to modify the membrane through incorporation of catalysts, either dispersed throughout the membrane or as an ultrathin layer. The catalyst would promote the chemical transformation of some of the gases to yield products that could be separated more easily. This approach has been discussed in a recent review ${ }^{29}$ and is being pursued by other investigators.

An active metal brazing technique was used to seal the alumina membrane tubes to a niobium spacer, which was ther brazed to stainless steel. When ceramic membranes are used at higher temperatures and pressures, the seals required to assemble the membrane into a configuration for testing or module fabrication become most important. Seals must be 
compatible with both the membrane materials and the structural component, and they must also be able to withstand both the temperature cycling and chemical environment encountered in process applications. Many seal materials become brittle and permeable to hydrogen under these conditions. Additional research and development is required to develop metal-to-ceramic seals with better mechanical strength and chemical resistance.

Inorganic membrane materials appropriate for gas separation are currently limited to certain metals, alumina, and silica, although membranes have also been produced from zirconia and titania. Other metal oxides and carbides, such as $\mathrm{HfO}_{2}, \mathrm{MgO}, \mathrm{SiC}, \mathrm{TiC}$, and $\mathrm{HfC}$ might be considered as membrane materials for use at higher temperatures.

Inorganic membranes are currently expensive, although they generally have a longer lifetime than polymeric membranes. This cost is expected to decrease as fabrication techniques improve. Ceramic membranes also have higher structural stability toward compaction and swelling, but they are more brittle. The surface area-to-volume ratio of inorganic membranes needs to be improved to decrease the size of the separation unit. This will improve as the membranes become thinner and the tube diameters decrease.

It is preferable in many coal conversion processes to retain the lower-molecular-weight gases, such as hydrogen, on the high-pressure side of the membrane while allowing the contaminant gases to permeate the membrane. ${ }^{30}$ Such separations will require a more reactive membrane (or membranes) which does not rely on Knudsen diffusion alone for gas transport, as discussed carlier. It would not be economical to recompress the gases and use additional separation stages. Consequently, present inorganic membranes are not readily adaptable to the Integrated Gasification Combined Cycle, Molten Carbonate Fuel Cell, and Direct Coal-Fueled Turbine cleanup processes but are more appropriate for hydrogen enrichment or recovery. 


\section{REFERENCES}

1. H. K. Lonsdale, "The Growth of Membrane Technology," J. Membrane Sci. 10, 81-181 (1982).

2. W. J. Schell and C. D. Hiouston, "Process Gas with Selective Membranes," Hydrocarbon Processing 61, 249-252 (1982).

3. C. S. Goddin, "Pick Treatment for High $\mathrm{CO}_{2}$ Removal," Hydrocarbon Processing 61, $125-130(1982)$.

4. W. H. Mazur and M. C. Chan, "Membranes for Natural Gas Sweetening and $\mathrm{CO}_{2}$ Enrichment," Chem. Eng. Prog. 78, 38-43 (1982).

5. S. L. Matson, J. Lopez, and J. A. Quinn, "Separation of Gases with Synthetic Membranes," Chem. Eng. Sci. 38, 503-524 (1983).

6. J. M. S. Henis and M. K. Tripodi, "The Developing Technology of Gas Separating Membranes," Science 220, 11-17 (1983).

7. R. S. Puragason and C. D. Houston, "Purification of $\mathrm{CO}_{2}-$ Containing Gas Streams with Membranes," Energy Progress 4, 54-6 (1984).

8. W. G. Perkins, "Permeation and Outgassing of Vacuum Materials," J. Vac. Sci. Technol. 10, 543-556 (1973).

9. R. R. McCaffrey, R. E. McAtce, A. E. Grey, C. A. Allen, D. G. Cummings, and A. D. Appelhans, "Synthesis, Casting, and Diffusion Testing of Poly [bis (trifluorocthoxy) phosphazene] Membranes," J. Membrane Sci. 28, 47-67 (1986).

10. R. R. McCaffrey and D. G. Cummings, "Gas Separation Properties of Phosphazene Polymer Membranes," Sep. Sci. Technol. 23, 1627-1643 (1988).

11. S. N. Gaeta, H. Zhang, E. Drioli, and S. Lora, "Polyorganophosphazene Membranes: Transport, Chemical and Thermal Characteristics," presented at the Third Annual Mecting of the North American Membrane Socicty, Austin, TX, May 1989.

12. B. Z. Egan, 1989, Using Inorganic Membranes to Separate Gases: R\&D Status Review, ORNL/TM-11345, Oak Ridge National Laboratory, Oak Ridge, TN.

13. J. Evans, I. R. Harris, and D. K. Ross, "A Proposed Method of Hydrogen Isotope Separation Using Palladium Alloy Membranes," J. Less-Common Metals 89, 407-414 (1983).

14. K. Haraya, Y. Shindo, T. Hakuta, and H. Yoshitome,"Separation of Hydrogen-Carbon Monoxide Mixtures with Porous Glass Membranes in the Intermediate Flow Region," J. Chem. Eng. Japan 19, 186-190 (1986). 
15. T. Kameyama, M. Dokiya, M. Fujishige, H. Yokokawa, and K. Fukuda, "Production of Hydrogen from Hydrogen Sulfide by Means of Selective Diffusion Membranes," Int. J. Hydrogen Energy 8, 5-13 (1983).

16. T. Yazawa, H. Tanaka, and K. Eguchi, "Effects of Pore Structure of Porous Glass on Gas Permeation," Nippon Kagaku Kaishi 2, 201-207 (1986).

17. R. J. Van Vuren, B. C. Bonekamp, K. Keizer, R. J. R. Uhlhorn, H. J. Veringa, and A. J. Burggraaf, "Formation of Ceramic Alumina Membranes for Gas Separation," in High Tech Ceramics, P. Vincenzini, ed., Elsevier Science Publishers, Amsterdam, pp. 2235-2245, 1987.

18. H. L. Fleming, "Latest Developments in Inorganic Membranes," presented at the Fifth Annual Membrane Technology/Planning Conference, Cambridge, MA, October 1987.

19. A. Larbot, J. P. Fabre, C. Guizard, and L. Cot, "Inorganic Membranes Obtained by Sol-Gel Techniques," J. Membr. Sci. 39, 203-212 (1988).

20. A. F. M. Leenaars, K. Keizer, and A. J. Burggraaf, "Porous Alumina Membranes," Chem Tech 1986, 560-564 (1986).

21. K. Itaya, S. Sugawara, K. Arai, and S. Saito, "Properties of Porous Anodic Aluminum Oxide Films as Membranes," J. Chem. Eng. Japan 17, 514-520 (1984).

22. L. Paulson, "Microporous Glass and Its Applications," presented at the Sixth Annual Membrane Technology/Planning Conference, Cambridge, MA, November 1988.

23. M. Konno, M. Shindo, S. Sugawara, and S. Saito, "A Composite Palladium and Porous Aluminum Oxide Membrane for Hydrogen Gas Separation," J. Membr. Sci. 37, 193 197 (1988).

24. D. E. Fain, "A Dynamic Flow-Weighted Pore-Size Distribution Test," presented at the Nineteenth Annual Meeting of the Fine Particle Society, Santa Clara, CA, July 19-22, 1988.

25. "Flow of Fluids Through Valves, Fittings, and Pipe," Technical Paper No. 410, Crane Co., 1969, pp. 3-5.

26. S.-T. Hwang and K. Kammermeyer, "Surface Diffusion in Microporous Media," Canadian Journal of Chemical Engineering 44, $82-89$ (1966).

27. R. J. R. Uhlhorn, M. H. B. J. Huis In't Veld, K. Keizer, and A. J. Burggraaf, "High Permselectivities of Microporous Silica-Modified $\Gamma$-Alumina Membranes," Journal of Materials Science Letters 8, 1135-1138 (1989).

28. D. E. Fain, G. E. Roettger, and D. E. White, 1991, Development of Ceramic Membranes for Gas Separation - FY 199() Development Activities, K/QT-413,

Oak Ridge K-25 Site, Oak Ridge, TN. 
29. J. N. Armor, "Catalysis with Permselective Inorganic Membranes," Appl. Catal. 49, $1-25(1989)$.

30. J. A. Poku and J. E. Plunkett, Assessment of Membrane Gas Separation Applications to METC Supported Technologies - Final Report, EG\&G Washington Analytical Services Center, Inc., Morgantown, WV, August 31, 1989. 


\section{PROJECT-RELATED PUBLICATIONS AND PRESENTATIONS}

1. B. Z. Egan, D. E. Fain, G. J. Kidd, and S. P. N. Singh, "Gas Scparations Using Inorganic Membranes," pp. 519-24 in Proceedings of the Eighth Annual Gasification and Gas Stream Cleanup Systems Contractors Review Meeting, Morgantown, West Virginia, DOE/METC-88/6092, Vol. 2, ed. V. P. Kothari and J. R. Longanbach, 1988.

2. D. E. Fain, "A Dynamic Flow-Weighted Pore Size Distribution Test," presented at the Nineteenth Annual Meetiag of the Fine Particle Society held in Santa Clara, California, July 19-22, 1988.

3. D. E. Fain, "Gas Separation Processes: Technology/Business Review," presented at the Sixth Annual Membrane Technology/Planning Conference held in Cambridge, Massachusetts, November 1988.

4. B. Z. Egan, R. R. Judkins, D. E. Fain, G. J. Kidd, G. E. Rocttger, S. P. N. Singh, and D. E. White, "Gas Separations Using Inorganic Membranes," pp. 510-18 in Proceedings of the Ninth Annual Gasification and Gas Stream Cleanup Systems Contractor Review Meeting, Mongantown, West Vinginia, DOE/METC-89/6107, Vol. 2, ed. R. A. Johnson and T. P. Dorchak, 1989.

5. D. E. Fain, "Development of Ceramic Membranes for Gas Separation," pp. 143-50 in Advanced Research and Technology Development Fossil Energy Materials Program Semiannual Progress Report for the Period Ending March 31, 1989, ORNL/FMP-89/1, compilers, R. R. Judkins and D. N. Braski, Oak Ridge National Laboratory, March 1989.

6. B. Z. Egan, S. P. N. Singh, D. E. Fain, G. J. Kidd, and D. E. White, "Gas Separations Using Inorganic Membrancs," pp. 29-35 in Fossil Energy Program Semiannual Progress Report for April 1988 through September 1988, ORNL-6522, ed. R. R. Judkins, Oak Ridge National Laboratory, 1989.

7. B. Z. Egan, Using Inorganic membranes to Separate Gases: R\&D Status Review, ORNL/TM-11345, Martin Marietta Energy Systems, Inc., Oak Ridge National Laboratory, 1989.

8. D. E. Fain, G. J. Kidd, Jr., G. E. Rocttger, and D. E. White, Development of Ceramic: Membranes for Gas Separation-FY 1989 Development Activities, K/QT-352, Martin Marictta Energy Systems, Inc., Oak Ridge Gaseous Diffusion Plant, 199().

9. D. E. Fain and G. E. Roctgicr, "Development of Ceramic Membranes for Gas Separation," pp. 183-94 in Proceedings of the Fourth Annual Conference on Fossil Energy Materials, ORNL/FMP-9()/1, compilers, R. R. Judkins and D. N. Braski, Oak Ridge National Laboratory, 1990. 
10. B. Z. Egan, R. R. Judkins, D. E. Fain, G. E. Roctger, S. P. N. Singh, and D. E. White, "Gus Separations Using Inorganic Membrancs," pp. 314-22 In Procecedings" of" the Tenth Annual Gasification and Gas Steam Cleanup Systems Contractor Review Meeting, Morgantown, West Virginia, DOE/METC 90/6115, Vol. I, ed. V. P. Kothani and J. L. Beeson, 199).

11. D. E. Fain, G. J. Kidd, C. E. Roettger, and D. E. White, "Development of Coramic Membrancs for Gas Separation," pp. 129-34 in Fossil Energy Advanced Research and Technology Development (AR\&TD) Materials Program Semiannual Progress' Report for the Period Ending September 30, 1989, ORNL/FMP-89/2, compilers, R. R. Judkins and D. N. Braski, Oak Ridge National Laboratory, 1990.

12. D. E. Fain, G. E. Roettger, and D. E. White, "Development of Ceramic Membranes for Gas Separation," pp. 83-90) in Fossil Energy Advanced Research and Technology Development (ARdTD) Materials Program Semiannual Progresss Report for the Period Ending September 30, 1990, ORNL/FMP-90/2, compilers, R. R. Judkins and P. 'T'. Carlson, Oak Ridge National Laboratory, 1990.

13. Chemical Technology Division Progress Report for the Period July 1, 1988 to September 30, 1989, ORNL-6596, Martin Marietta Energy Systems, Inc., Oak Ridge National Laboratory, March 1990.

14. D. E. Fain, G. E. Roettger, and D. E. White, Development of Ceramic Membranes for Gas Separation - FY 1990) Development Activities, K/QT-413, Martin Maricla Encrgy Systems, Inc., K-25 Sitc, June 1991.

15. D. E. Fain, G. E. Roctlger, and D. E. White, "Development of Ceramic Membranes for High-Temperature Hydrogen Separation," pp. 55-64 in Proceedings" of the Fifth Annual Conference on Fossil Energy Materials, ORNL/FMP-91/1, compilers, N. C. Cole and R. R. Judkins, Oak Ridge National Laboratory, 1991.

16. B. Z. Egan, D. E. Fain, G. E. Roettger, and D. E. White, "Separating Hydrogen frem Coal Gasilication Gases with Alumina Membranes," presented at the ASME International Gas Turbine and Acroengine Congress and Exposition, Orlando, Florida, June 1991. Preprint No, 91-GT-132.

17. B. Z. Egan, D. E. Fain, G. E. Roeltger, and D. E. White, "Separating Hydrogen from Coal Gasification Gases with Alumina Membranes," Journal of Engineering for Gas Turbines and Power, in press. 


\section{ACKNOWLEDGMENTS}

Excellent technical assistance was provided by Dale Adcock, Betty Evans, and Jim Hewitt. Many others contributed through helpful discussions and suggestions. Tim Kent helped to evaluate the test data. Mike Santella provided information on metal-to-ceramic scals. The permeability test system was built by John Norris. Rod Judkins, George Kidd, Jr., John Vance, and Terry Donaldson participated in many discussions throughout the program. Editorial assistance was provided by Vicki Hinkel. We are grateful to Dar Cicero and Lisa Jarr ol the Morgantown Energy 'Technology Center for their support and encouragement. 
ORNL/TM-12068

\section{Internal Distribution}

1. K. D. Adcock

2-6. J. 'T. Bell

7. J. T. Bradbury

8. C. H. Brown

9. C. H. Byers

10. Р. T. Carlson

11. N. C. Cole

12. E. D. Collins

13. A. G. Crolf

14. T. L. Donaldson

15-19. B. Z. Egan

20. B. S. Evans

21-25. D. E. Fain

26. W. Fulkerson

27. R. K. Genung

28. J. D. Hewitl

29. J. R. Hightower

30)-31. V. T. Hinkel

32. E. K. Johnson

3.3. R. R. Judkins

34. G. J. Kidd, Jr.

35. J. R. Palmer

36. B. D. Pallon

37. M. L. Poutsma

38. A. S. Quist

39-43. G. E. Rocltger

44-48. S. P. N. Singh

49. J. M. Vance

5()-54. D. E. White

55. R. G. Wymer

56. Central Rescarch Library

57-58. Laboratory Records Department

59. Laboratory Records, RC

60). ORNL Patent Section

61. Y-12 Technical Library, Document Reference Section 


\section{Extcrnal Distribution}

62. S. B. Alpert, Electric Power Rescarch Institute, P. O. Box 10412, 3412 Hillview Avenue, Palo Alto, CA 94303.

63. M. A. Anderson, University of Wisconsin - Madison, Civil and Environmental Engineering, Water Chemistry Program, 660) North Park Strect, Madison, WI 537()6.

64. R. A. Bajura, DOE Morgantown Energy Technology Cenicr, P. O. Box 880, Morgantown, WV 265() 5$.

65. R. C. Bedick, DOE Morgantown Energy Technology Center, P. O. Box 880, Morgantown, WV 265() 5$.

66. D. J. Beccy, FE-13, DOE Office of Fossil Encrgy, Washington, DC 20545

67. J. J. Brown, Jr., Department of Materials Enginecring, Virginia Polylechnic Institute and Statc University, Blacksburg, VA 2460)1

68. J. P. Carr, FE-24, DOE Olfice of Fossil Energy, Washington, DC 20545

69-73. D. C. Ciccro, DOE Morgantown Energy Technology Center, P. O. Box 880, Morgantown, WV 265()5

74. F. L. Culler, Electric Power Research Institute, P. O. Box 10412, Palo Alto, CA 94303

75. S. J. Dapkunas, Materials Building, National Institute of Standards and Technology, Gaithersburg, MD 20899

76. D. J. Driscoll, DOE Morgantown Energy Technology Center, P. O. Box 880, Morgantown, WV 265()5

77. L. Gasper-Galvin, DOE Morgantown Energy Technology Center, P. O. Box Sis(), Morgantown, WV 265()5

78. R. L. Goldsmith, CeraMem Corporation, 12 Clematis Avenue, Waltham, MA (02154

79. V. L. Hill, Gas Rescarch Institute, 8600 West Bryn Mawr Avenue, Chicange, IL 606.31

8(). Assistant Manager for Energy Research and Development, DOE Oak Ridge Field Oltice, P. O. Box 2()()1, Oak Ridge, TN 37831-860)(

81. N. T. Holcombe, DOE Morgantown Energy Technology Center, P. O. B Box 88(), Morgantown, WV 26505 
82. W. J. Huber, DOE Morgantown Encrgy Technology Center, P. O. Box 880, Morgantown, WV 26505

83. D. Jansen, Netherlands Energy Research Foundation, 3 Westerduinweg, P. O. Box 1, $1755 \mathrm{ZG}$ Petten (NH), The Netherlands

84. L. A. Jarr, DOE Morgantown Energy Technology Center, P. O. Box 880, Morgantown, WV $265(15$

85. R. A. Johnson, DOE Morgantown Energy Technology Center, P. O. Box 880, Morgantown, WV 26505

86. R. W. Koch, DOE Morgantown Energy Technology Center, P. O. Box 88(), Morgantown, WV 26505

87. D. V. Laciak, Corporate Science and Technology Center, Air Products and Chemicals, Inc., Allentown, PA 18195

88. P. K. T. Liu, Alcoa Separations Technology Division, 181 Thorn Hill Road, Warrendale, PA 15086

89. J. R. Longanbach, DOE Morgantown Encrgy Technology Center, P. O. Box 880, Morgantown, WV 26505

90. T. P. McMahon, DOE Morgantown Energy Technology Center, P. O. Box 880, Morgantown, WV 26505

91. W. Moore, FE-231, DOE Office of Fossil Encrgy, Washington, DC 20,545

92. M. W. Pitt, FE-231, DOE Office of Fossil Encrgy, Washington, DC 20545

93. D. L. Roberts, SRI International, 333 Ravenwood Avenue, Menlo Park, CA 94()25

94. W. M. Sonnett, Office of Industrial Programs, Conservation and Renewable Energy, U.S. Department of Energy, 1000) Independenec Ave. SW, Washington, DC 20585

95. S. A. Stern, Department of Chemical Enginecring and Materials Science, Syracuse University, Syracuse, NY 13244

96. M. C. Williams, DOE Morgantown Energy Technology Center, P. O. Box 880, Morgantown, WV 26505

97. K. E. Woodeock, Gas Rescarch Institute, 8600 West Bryn Mawr Avenue, Chicago, IL 60631

98-107. DOE Office of Scientific and Technical Information, P. O. Box 62, Oak Ridge, 'TN 37831 

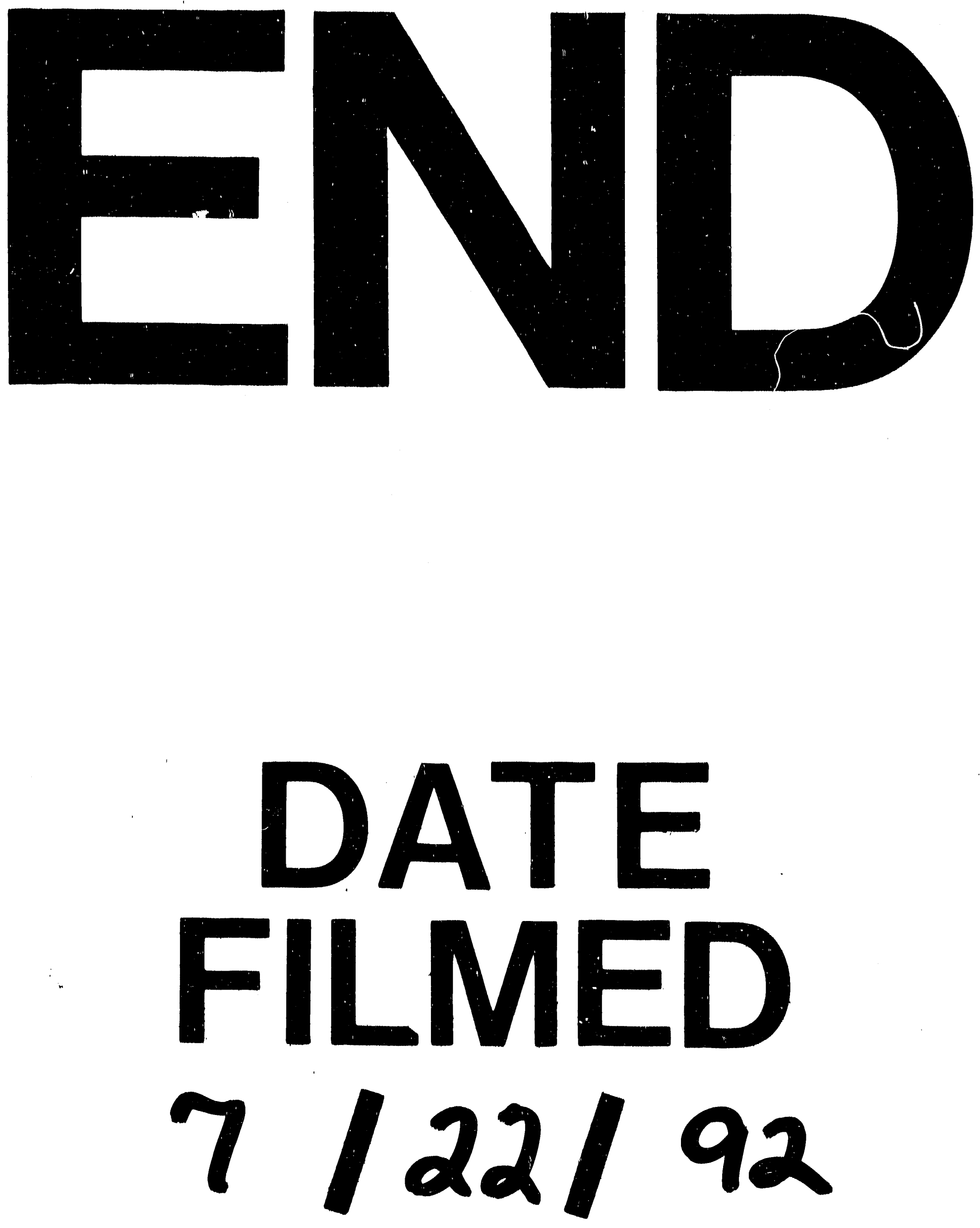
